\title{
Pesquisadores e suas táticas discursivas no debate sobre populações tradicionais e proteção à biodiversidade
}

\section{Researchers and their Discursive Tactics in the Debate on Traditional Populations and Protecting Biodiversity}

\author{
Cleyton GERHARDT*
}

\begin{abstract}
RESUMO
O debate em torno da relação entre biodiversidade e populações tradicionais encontra-se hoje extremamente dividido. Tal ambiente polarizado se expressa na interface que marca o fazer científico e a ação política de pesquisadores que se interessam pelo tema. Como tentarei mostrar, um dos efeitos desse fenômeno tem sido a cristalização de uma controvérsia geral: de um lado, uma busca por evidências por parte dos que defendem a tese de que populações tradicionais sempre depredaram a natureza; de outro, esforço semelhante de cientistas que passam a procurar evidências que comprovem que tais populações protegem a biodiversidade. Como resultado, temos um debate em que cientistas e suas pesquisas tornam-se armas de convencimento poderosíssimas. Como num julgamento, suas pesquisas servem para acusar ou defender populações tradicionais e/ou áreas protegidas, as quais cumprem o papel de rés ou de vítimas. Como decorrência, especialistas que investem nesta discussão são chamados constantemente a fazer escolhas argumentativas. Será justamente sobre elas que me aterei no corpo do artigo. Visando acessar o universo discursivo perito sobre políticas de apoio às populações tradicionais e políticas mais estritas de proteção à biodiversidade, tomo os antagonismos que daí emergem como laboratório para observar a dinâmica de argumentações e contra-argumentações que se seguem. Ao final, problematizo a possibilidade de que, ao discutir a questão a partir da lógica do "ou isto ou aquilo" (populações tradicionais "conservam" ou "destroem" biodiversidade), há grande chance de que as infindáveis contestações de parte a parte nos levem a uma controvérsia analiticamente estéril.
\end{abstract}

Palavras-chave: populações tradicionais; biodiversidade; discurso científico.

\begin{abstract}
The debate over the relationship between biodiversity and traditional populations today is much divided. Such a polarized atmosphere is expressed in the interface that marks the researchers' scientific work and political action around the subject. As I argue, one of the effects of this phenomenon has been the crystallization of a general controversy: on the one hand, a search for evidence from those who support the thesis that traditional peoples always vandalized nature; on the other hand, a similar effort from
\end{abstract}

\footnotetext{
"Agrônomo, Doutor em Ciências Socais. Professor adjunto da Universidade Federal do Rio Grande do Sul (UFRGS) e pesquisador do Programa de Pós-Graduação em Desenvolvimento Rural (PGDR). Email: cleytonger@hotmail.com.
} 
scientists that look for evidence to prove that these peoples protect biodiversity. As a result, we have a debate in which scientists and their research become very powerful weapons of persuasion. Like in a trial, their researches are used to prosecute or defend traditional populations and/or protected areas, which play the part of defendants or victims. As a result, experts who invest in this discussion are often called on to make argumentative choices. These argumentative choices are the main point of this article. Aiming at accessing the universe of expert discourse on policies in support of traditional populations and stricter policies to protect biodiversity, I will then take the antagonisms that emerge as a laboratory for observing the dynamics of arguments and counterarguments that follow. Finally, I question the possibility that in discussing the issue from the logic of "either/or" (traditional populations either "save" or "destroy" biodiversity) chances are that the endless disputes for either party lead to an analytically barren controversy without answers.

Key-words: traditional peoples; biodiversity; scientific discourse.

\section{Introdução ${ }^{1}$}

Quando a bala vem por cima, companheiro, se abaixemo; quando a bala vem por baixo, companheiro, nós pulemo; mas se a bala vier no meio, há! fazemo a bala voltar!

Gilberto Carvalho e Raul Pereira (1976) ${ }^{2}$

O debate em torno da relação entre proteção à biodiversidade e garantia de direitos às populações tradicionais - seja pelo viés que for (técnico, científico, ético, político, jurídico, administrativo) ou a dimensão envolvida (local, regional, nacional, internacional) - caracteriza-se por ser um ambiente extremamente dividido ${ }^{3}$. De fato, se há um consenso entre interessados no tema, é o de que discuti-lo implica entrar num universo discursivo marcado pelo confronto de ideias e visões divergentes, dele emergindo posturas e posicionamentos contumazes.

Deste ambiente controvertido envolvendo intensa discussão sobre políticas públicas, interesses locais e legislação voltada ao disciplinamento do uso de recursos naturais, cresceu na última década o interesse de pesquisadores. Ainda que com enfoques distintos, cientistas de diversas áreas têm produzido farta literatura sobre o assunto, sendo que artigos, coletâneas, livros, dissertações, teses e outras publicações são hoje numerosos e ricos em termos de recorte, abordagem, conteúdo, amplitude e qualidade. Mas quando cientistas naturais (ecólogos, biólogos, botânicos, oceanógrafos etc.), cientistas sociais (antropólogos, cientistas políticos, historiadores, sociólogos, economistas), cientistas vindos de disciplinas aplicadas (agrônomos, advogados, engenheiros florestais, biólogos da conservação, jornalistas) ou de "fronteira" (geógrafos, geólogos) começam a se pronunciar, vemos que outra disputa interpretativa (também marcada pelo dissenso e, por vezes, por ácidos diálogos acadêmicos) vem se desenvolvendo na interface que marca o fazer científico e a ação política destes profissionais nas demais arenas públicas.

Como tentarei mostrar, um dos efeitos desta procura incessante tem sido a cristalização de uma controvérsia geral. Soma-se a isto o fato de que, devido ao fato dos pesquisadores envolvidos possuírem trajetórias sociais muito peculiares, mas, também, à forte interferência de motivações ideológicas e valores éticos e morais distintos (ver GERHARDT, 2008), o debate e o ambiente belicoso por trás dele têm se polarizado entre duas grandes teses gerais. De um lado, há uma frenética e generalizada busca por evidências (sejam elas baseadas em casos, exemplos,

\footnotetext{
${ }^{1}$ Este artigo foi escrito tendo como base tópico específico de minha tese de doutorado intitulada Pesquisadores, populações locais e áreas protegidas: entre a instabilidade dos "lados" e a multiplicidade estrutural das "posições" (GERHARDT, 2008).

${ }^{2}$ Trecho de Leão do Caverá, canção apresentada em 1976 por Leopoldo Rassier e os Tropeiros do Ibirapuitã durante a VI Califórnia da Canção Nativa (Uruguaiana/RS). ${ }^{3}$ A Lei que instituiu o SNUC (BRASIL, 2000) adotava, em seu texto original, o termo "populações" (acoplado aos adjetivos "tradicionais", "locais", "residentes", "humanas" e "extrativistas") como nomeação padrão. Porém, após o I Encontro dos Povos e Comunidades Tradicionais, realizado em Luiziânia (GO), em 2006, o Decreto Presidencial n. 6040, de 7 de fevereiro de 2007, alterou esta situação inserindo, em seu artigo terceiro, a definição de Povos e Comunidades Tradicionais (preterindo, portanto, o termo população) como "grupos culturalmente diferenciados e que se reconhecem como tais, que possuem formas próprias de organização social, que ocupam e usam territórios e recursos naturais como condição para sua reprodução cultural, social, religiosa, ancestral e econômica, utilizando conhecimentos, inovações e práticas gerados e transmitidos pela tradição". Porém, visando reunir comunidades e povos num mesmo termo, adotarei populações tradicionais como categoria geral.
} 
números, dados, informações, relatórios, relatos, reportagens, denúncias etc.) por parte dos que afirmam que populações tradicionais (do passado ou do presente) sempre depredaram a natureza; de outro, o mesmo esforço pode ser visto entre cientistas que passam a procurar evidências que comprovem que tais populações ajudam a proteger a biodiversidade.

Como um número razoável de especialistas investe nesta discussão a partir de um viés polarizado, está em curso uma longa batalha (que já dura cerca de 15 anos) cujos participantes são chamados constantemente a fazer certas escolhas argumentativas. Será justamente sobre estas últimas que me aterei no presente artigo. Ainda que não se opte explicitamente por um dos lados da controvérsia - assumindo postura mais cética e agnóstica ou, então, reivindicando neutralidade -, a intensa mobilização que ela provoca dentro e fora do meio acadêmico tende a fazer com que seja reproduzida e incorporada aos seus discursos. Com isso, gera-se uma relativa naturalização acerca da sua existência, ou seja, uma aceitação tácita sobre a pertinência da discussão (no sentido de que vale a pena debatê-la e, por conseguinte, defender posições).

De fato, quando escrevemos sobre a relação entre biodiversidade e populações tradicionais, há toda uma sutileza em problematizá-la. Como a própria apresentação do tema está em disputa, a luta já se inicia no momento de formular questões e indagações. Como ilustração, posso sugerir algumas: "a proteção da biodiversidade é incompatível com a presença de comunidades quilombolas em unidades de conservação (daqui para frente UCs) de proteção integral?"; "quais práticas de manejo executadas por povos indígenas poderiam ser incorporadas às políticas de conservação da biodiversidade?"; "como permitir que populações tradicionais colaborem de forma autônoma e ativa para a proteção de amostras representativas de nossos ecossistemas"?; "como controlar e ensinar tais populações a cumprirem os objetivos das políticas de proteção à biodiversidade?". Como vemos, só o modo de propor perguntas para refletir sobre o tema já tende a orientar a conotação das argumentações subsequentes.

Levando em conta o contexto mais amplo, o que está em jogo por trás desta controvérsia refere-se ao viés a ser conferido a duas políticas públicas: a delimitação, plane- jamento, criação e gestão de áreas protegidas e a garantia de direitos não só aos povos e comunidades tradicionais, mas às populações rurais econômica e socialmente fragilizadas 4 . Ocorre que, ao colocar a questão na forma do "isto ou aquilo", abre-se espaço para que se possa não só explicar, mas, literalmente, julgar (positiva ou negativamente) grupos sociais que vivam em áreas consideradas prioritárias à conservação. Afinal, considerando a farta literatura existente, não será difícil achar autores cujos trabalhos ou enfatizam a contribuição destas populações para a proteção, manutenção (em alguns casos, aumento) da biodiversidade ou, ao contrário, apontam o caráter prejudicial, danoso e deletério daquelas para esta última.

Como resultado, está em andamento uma guerra em que cientistas e suas pesquisas adquirem expressivo poder de convencimento, passando a influenciar não só colegas que, em seus estudos, elegem tal controvérsia como objeto de pesquisa, mas, também, profissionais incumbidos de propor e planejar políticas públicas (via órgãos governamentais ou ONGs) e técnicos que têm a incumbência de implantar, gerir e fiscalizar seu cumprimento nas diferentes localidades. Neste caso, há o uso explícito e generalizado de estudos científicos (que se tornam uma espécie de moeda corrente neste ambiente polêmico) destinados a realçar uma ou outra tese, bem como suas derivações e relativizações. Como num tribunal, cientistas, ao produzirem suas pesquisas, atuam então como acusadores públicos ou, ao contrário, defensores públicos de populações tradicionais e/ou áreas protegidas, as quais cumprem o papel de rés ou de vítimas.

Visando acessar o universo discursivo perito sobre políticas de apoio às populações tradicionais e, também, sobre estratégias mais estritas de proteção à biodiversidade, tomarei a referida controvérsia como objeto de análise. Esta opção vincula-se não só à capacidade desta polêmica mobilizar a atenção de número expressivo de especialistas, mas também à possibilidade de, através dela, visualizar táticas discursivas que passam a induzir, fabricar e reproduzir "efeitos de verdade" (FOUCAULT, 1979; 1997). Também no presente caso certas deduções, assertivas e conclusões, ao serem apropriadas, recicladas, bricoladas, integradas e usadas de diferentes formas em textos científicos, "produzem e fazem circular discursos que funcionam como verdade, que passam por tal e que detêm, por este motivo,

\footnotetext{
${ }^{4}$ Como a opção pelo termo população tradicional, adotarei o termo "áreas protegidas" por ser mais amplo do que "unidade de conservação". Na legislação, esta se refere a espaços físicos delimitados cuja titularidade (excetuando as Reservas Particulares do Patrimônio Natural - RPPNs) pertence ao Estado. Já a expressão área protegida, além de incluir todas as categorias de unidades de conservação, inclui ainda as chamadas "reservas legais", "áreas de preservação permanente", mas, igualmente, "terras indígenas" e "terra de quilombos".
} 
poderes específicos" (FOUCAULT, 1979, p. 231). Sob esta perspectiva, o presente texto recai sobre o modo como tal procedimento, premeditado ou não, surge quando cientistas, ao transformar argumentos, teses ou hipóteses em artefatos discursivos, escrevem sobre populações tradicionais e biodiversidade. Em suma, interessa aqui atentar para a construção da argumentação no sentido desta última cumprir a função (como meio para se atingir um fim) de enfraquecer adversários e/ou fortalecer aliados.

Para tanto, faço uso de instrumentos analíticos adotados por Bruno Latour (2000) ao descrever a dinâmica confrontacional que caracteriza a formação de controvérsias científicas. No caso das questões aqui apresentadas, debates, críticas e discussões conformam pequenas batalhas argumentativas em uma guerra mais ampla, ligada à fixação de "efeitos de realidade" (LATOUR, 1994) por dentro e para fora do campo acadêmico. Complementando contribuições foucaultianas vistas acima, Latour (1994, p. 80), ao apontar o "trabalho dos intermediários" nas sociedades contemporâneas, mostra como estes últimos, quando "dotados da capacidade de traduzir aquilo que eles transportam, de redefini-lo, desdobrá-lo, e também traí-lo", tornam-se "mediadores". Seja com aspiração prescritiva, normativa, propositiva, seja com viés crítico, reflexivo, analítico, cientistas possuem a incumbência (autodelegada e socialmente aceita) de traduzir a realidade, seja ela associada a processos sociais ou fenômenos naturais. No caso enfocado, tais mediadores constituem um conjunto de agentes peritos que atuam como intermediários nas intricadas redes sociais formadas a partir do cruzamento entre o fazer científico e o universo das políticas públicas voltadas, por um lado, à proteção, controle e uso de recursos naturais e, por outro, à garantia de direitos a grupos sociais específicos.

Contudo, obviamente não tenho aqui a menor intenção de "solapar a pretensão da ciência à verdade" ou sugerir que "se algo for fabricado, é falso" (LATOUR, 2001, p. 152). Minha ênfase se desloca e se descola desta infértil "batalha polarizada contra a verdade e a realidade" para recair sobre a "fabricação de artefatos discursivos" (LATOUR, 2001, p. 148). Tal como nos exemplos descritos pelo autor, a tentativa de fixar, via argumentos e evidências, pontos de vista pertinentes sobre a relação entre biodiversidade e populações tradicionais gera uma concorrência entre pesquisadores, os quais fazem uso de seu arsenal discursivo buscando, ao mesmo tempo, mobilizar seus "aliados" (sejam eles outros pesquisadores ou não) com vistas a persuadir seus colegas. Ao se acionar o léxico científico e seus distintos dialetos, todo um jogo de questionamentos e acusações recíprocas se inicia, sendo os leitores convidados a participar destas pequenas batalhas regidas por dois caminhos possíveis: tornar nossos argumentos fatos inquestionáveis e indiscutíveis ("ciência pronta") ou, ao contrário, destruir discursivamente esta condição de inquestionabilidade do outro ("ciência em construção") (LATOUR, 2000). Como resultado, enquanto certos fatos, eventos e casos são "camuflados ou obscurecidos", outros são iluminados e realçados (LATOUR, 2001, p. 152).

Tal situação me levou a identificar, a partir da seleção prévia de autores de diversas áreas do conhecimento científico tidos como referência nos debates atuais sobre populações tradicionais e biodiversidade, "que tipo de direção é tomada pelo pessoal que discute e que tipo de elementos novos eles arranjam, arregimentam ou seduzem a fim de convencer os colegas" (LATOUR, 2000, p. 33). O que permitiu visualizar o modo como peritos refutam, se esquivam ou se livram de dificuldades criadas tanto pelos seus objetos/sujeitos de pesquisa como pelos colegas com quem debatem; ou, ainda, como retrabalham e refazem, ao seu modo, argumentos, fatos, evidências que, anteriormente, foram usados para atacar seus pontos de vista.

\section{Em caso de controvérsia, traga exemplos, cite casos, mencione dados, use referências}

Quando analisamos uma controvérsia, procedimentos distintos podem ser adotados para tornar argumentos mais eficientes. Um deles é trazer casos já documentados por outros cientistas que referendem nossas afirmações. Vejamos primeiro como isso aparece em autores que se inclinam para a hipótese de que populações tradicionais seriam incompatíveis com a proteção, in situ, da biodiversidade. Uma alternativa é resgatar casos em que grupos humanos teriam contribuído para a diminuição de espécies (sobretudo, ameaçadas de extinção), causado danos ao equilíbrio biocenótico em algum ecossistema ou provocado outro tipo de degradação ambiental. Dourojeanni (2001, p. 74), engenheiro florestal com longa trajetória voltada ao referido debate e crítico voraz do papel deletério das populações tradicionais sobre a biodiversidade, percebeu argutamente como trazer exemplos pode ser decisivo para legitimar pontos de vista. No caso de povos indígenas, o autor (2001, p. 74) alega que não seria difícil encontrar "casos en que poblaciones indígenas y supuestamiente 
indígenas estan destruyendo relictos naturales". O mesmo o fazem Dourojeanni e Jorge-Pádua (2001, p. 188) para a "pesca tradicional"s.

[...] está bem demonstrado que a pesca, inclusive a pesca tradicional, tem forte efeito depressivo nos recursos. Um exemplo recente provém do Parque Nacional das Ilhas Galápagos [...], onde se concluiu que a pesca tradicional tem impacto negativo muito significativo sobre o tamanho e a densidade das espécies e, ainda mais grave, que este impacto apresenta efeito cascata sobre toda comunidade biótica da área (Ruttenberg, 1999). Nada de novo sob o sol... Antigos trabalhos de Pierret e Dourojeanni $(1966,1967)$ já haviam constatado o mesmo para [caça e pesca de] populações tradicionais de ribeirinhos amazônicos. Existem, por certo, inúmeros trabalhos no mundo inteiro que corroboram estes dados, entre eles vários referentes à Amazônia (Redford e Sterarman, 1989; Martins, 1993; ChaseSmith, 1996; Terborgh, 1999; Peres, 2000).

Além do "exemplo recente" (quanto mais recente, mais eficaz) e de "antigos trabalhos", os cinco estudos citados reforçam a alegação de que a "pesca tradicional tem forte efeito depressivo nos recursos". Com efeito, é comum referências terem função de garantir veracidade (como diz o autor, elas "corroboram"), no caso, à alegação de que haveria "inúmeros" estudos indicando que o mesmo ocorreu "no caso da caça e da pesca por populações tradicionais". Ademais, o fato de o próprio autor ter "contatado" in loco aumenta sua autoridade para falar sobre o tema. Em suma, Dourojeanni e Maria Tereza Jorge-Pádua nos dizem algo como: "olha, além da nossa própria experiência com o tema, não estamos sós ao dizer o que dizemos, mas ao contrário, muito bem acompanhados em nossa afirmação".

Sobre exemplos como este que teriam ocorrido no Brasil há várias alternativas. Porém, ater-me-ei a dois casos emblemáticos que têm monopolizado o discurso de que o manejo de recursos naturais executado por populações tradicionais seria insustentável: citações sobre os Pataxó do Monte Pascoal (Bahia) e sobre os Guarani da Ilha do Cardoso (São Paulo). Como na referência aos parques quenianos que veremos a seguir (embora com efeito contrário), essas duas etnias são o alvo preferido quando se deseja trazer exemplos que reforcem a hipótese acima. No caso dos Pataxó, Olmos et al. (2001, p. 291) são taxativos em suas críticas:

um dos casos mais desastrosos de incompatibilidade entre áreas protegidas e "populações tradicionais" é o caso dos Pataxó no Parque Nacional do Monte Pascoal relatado por Redford (1989), Rocha $(1995,1997,1998)$ e Dean (1996) [...]. Em 1980, 8.627 dos 22.500 ha do parque foram desmembrados e alocados para uso pelos Pataxó, que imediatamente se engajaram na venda de madeira e desmatamento da área [...]. Os Pataxó desmataram mais de $50 \mathbf{~ k m}^{2}$ da antiga área protegida, além de se engajarem na retirada seletiva de madeira e piaçava do interior da área "protegida". Vários incêndios iniciados na área Pataxó adentraram o parque [...]. Qualquer um que já esteve na região percebeu o intenso comércio de animais silvestres ao longo das estradas. Os Pataxó, imunes à lei, são atores importantes nesse comércio e o parque nacional é uma das principais fontes de animais, especialmente muitas espécies ameaçadas (Martuscelli, 2000). Os Pataxó também têm vendido artesanato que utiliza partes de animais, incluindo penas de espécies ameaçadas.

Este grupo de 12 autores liderados por Fábio Olmos (renomado ornitólogo especialista em biologia da conservação) defende a tese de que haveria "incompatibilidade entre áreas protegidas e "populações tradicionais", sendo seu objetivo comprová-la no artigo citado 6 . Para tanto, são enumeradas práticas ("venda de madeira", "desmatamento", "incêndios", "comércio de animais" etc.) que reforçam tal possibilidade, sendo que, quanto mais desastrosas forem estas, maior o efeito persuasivo 7 . Dedicando uma seção

\footnotetext{
${ }^{5} \mathrm{O}$ uso do negrito nas citações aqui reproduzidas visa chamar a atenção do leitor para comentários subsequentes.

${ }^{6} \mathrm{O}$ artigo traz o sugestivo título de "Correção política e biodiversidade: a crescente ameaça das 'populações tradicionais' à Mata Atlântica". Publicado um ano após a aprovação do SNUC (portanto, marcado pelo clima beligerante deste debate que durou quase uma década), constitui ataque frontal à permanência de populações dentro de UCs, ao valor (para a conservação) de seus conhecimentos sobre o ambiente onde vivem e à ideia de que poderiam se tornar parceiros ativos no que se refere ao manejo de recursos naturais nestas áreas. Além do tom acusatório em relação à atuação de cientistas sociais, assinam o texto 12 renomados cientistas vindos de disciplinas como zoologia, botânica, genética, engenharia florestal, biologia da conservação e paleontologia, sendo eles: Fábio Olmos, Jorge Albuquerque, Mauro Galetti, Miguel Milano, Ibsen Câmara, Adelmar Coimbra-Filho, José Pacheco, Claudia Bauer, Carlos Pena, Thales Freitas, Marco Pizo e Alexandre Aleixo. ${ }^{7}$ Para dar credibilidade às suas alegações, os autores citam pesquisas de colegas. Voltarei a tratar desta tática no item seguinte.
} 
inteira à "questão dos Guarani na Mata Atlântica" (vistos pelos autores como "um problema"), adotam tática semelhante à de Dourojeanni (2001) ao comentarem a "invasão" da "pátria Guarani” à Ilha do Cardoso:

[...] em 1995-96 vários laudos técnicos foram elaborados pelo Instituto Florestal, Instituto Geológico e Instituto de Botânica de São Paulo [...]. Todos os laudos apontavam danos ambientais significativos provocados pelos Guarani no ecossistema insular [...]. Visita recente (setembro de 2000) de pesquisadores da UNESP na aldeia da Ilha do Cardoso revelou [...] [que] cerca de 5 ha de mata nativa haviam sido derrubados recentemente e foram encontrados vários restos de macacos, porcos do mato e outros animais abatidos pelos índios, além de grande número de cães domésticos pertencentes a índios à solta no parque (OLMOS et al., 2001, p. 296).

Para dar sustentação à sua tese geral - algo como: os Guarani depredam os ambientes onde vivem ou por onde passam e, por isso, devem ser mantidos longe das áreas prioritárias à conservação da biodiversidade -, Olmos et al. (2001) trazem para seu lado "laudos técnicos", "visita recente de pesquisadores" e a constatação destes, feita no próprio local, de que índios teriam causado "danos". Para fortalecer seu argumento, inserem evidências baseadas em documentos oficiais ("laudos") produzidos por peritos de órgãos também oficiais ("técnicos" de três "institutos") e dados empíricos ("restos de animais abatidos pelos índios") coletados por pessoas detentoras da devida competência ("pesquisadores"). O caráter oficial dos laudos é ainda reforçado pelo fato de, segundo os autores, "todos" eles atestarem a veracidade de suas afirmações. Estas, por sua vez, são ratificadas pela "visita" de "pesquisadores" que teriam verificado a ocorrência de "danos" ambientais supostamente causados pelos Guarani. Por fim, a alusão a estes "danos" traz à cena discursiva um forte elemento de convencimento: a referência a fatos "objetivos" ("mata nativa derrubada", "animais abatidos" e "cães soltos no parque") que também robustecem as observações.

Mais forte ainda, no caso de argumentações que sigam esta linha, é o uso de pesquisas específicas que adotem procedimentos baseados em dados estatísticos. É o caso de um diagnóstico, conduzido por Galetti, Bernardo e o próprio Olmos (2004, p. 251), acerca da "situação das aves e mamíferos [...] (utilizados para caça) na Ilha do Cardoso", sendo o objetivo central dos autores verificar "se a atividade Guarani Mbyá e caiçara [...] influencia a abundância de mamíferos e aves de grande porte dessa UC de Proteção Integral" (Ibid.). Reproduzo alguns resultados e conclusões do estudo sobre a "atividade" Guarani e caiçara:

[...] encontramos correlação altamente significativa entre abundância de mamíferos cinegéticos e distância de habitações humanas no Peic $\left(\mathbf{r}^{\mathbf{2}}=\mathbf{0 , 0 9} ; \mathbf{F}=\mathbf{6 , 2 7}\right.$; $\mathbf{P}=\mathbf{0 , 0 1 4})[\ldots]$. Os dados nos dão evidências claras que a abundância de mamíferos no Peic é intimamente relacionada à distância das habitações humanas mais próximas e que os ocupantes do Parque, tanto índios como caiçaras, têm um impacto negativo bastante evidente. [...] a chance de permanência das espécies na ilha é reduzida. É patente o conflito entre a manutenção de populações humanas no Parque e a biota que este deveria proteger, e que a UC não está sendo gerenciada de forma a cumprir as funções para as quais foi criada [...]. É bastante claro que as atividades dos índios são incompatíveis com as funções para as quais o Peic foi criado e para a perenidade de seus atributos. Devem ser buscadas alternativas para a subsistência da comunidade que não envolvam a destruição de uma biota já gravemente impactada pelo histórico da ação humana na ilha (GALETTI et al., 2004, p. 251-253).

Uma diferença em relação aos textos anteriores é que esta pesquisa não parte de casos particulares para generalizar uma hipótese, ou seja, há um foco definido centrado na análise da situação de um parque específico onde residem ou transitam caiçaras e guaranis. Contudo, como veremos a seguir, estudos como este passam a ser, posteriormente, apropriados por outros autores, transformando-se então em mais um artefato para a guerra, mais precisamente, munição de grande efeito discursivo e poder persuasivo.

$\mathrm{O}$ artigo tem ainda a seu favor - além do rigor que os próprios autores costumam exigir de seus colegas - "dados" que apontam "evidências claras" sobre a "incompatibilidade" das "atividades" "com as funções" do parque. Após a conduta de caiçaras e guaranis ser testada e embutida numa fórmula (" $\mathrm{r}^{2}=0,09 ; \mathrm{F}=6,27 ; \mathrm{P}=0,014$ "), passa a ser possível julgá-la segundo critérios previamente escolhidos e concluir que ambos "têm impacto negativo bastante evidente". Mas, curiosamente, caiçaras e guaranis, ao serem vistos como uma das variáveis da pesquisa (suas condutas são medidas e, pelas recomendações, passíveis de serem 
manipuladas e controladas de modo a diminuir seu "impacto negativo"), adquirem caráter invariável noutro sentido, a saber: ao isolar tais práticas de seu contexto mais amplo, estas deixam de possuir variabilidade interna. Em suma, todos os guaranis e caiçaras são vistos como atuando de forma idêntica, não havendo diferenças tanto entre um e outro como entre eles próprios.

Vejamos agora como exemplos e estudos de caso surgem nos trabalhos daqueles que defendem a hipótese geral de que populações tradicionais podem contribuir para proteger a biodiversidade. Neste caso, uma alternativa é procurar locais onde, ao contrário da antítese acima, a retirada das pessoas é que teria provocado dano ambiental. Diegues (2000, p. 35) traz algumas destas situações:

\section{[...] existem casos em que a exclusão dos humanos} resultou em perda da biodiversidade. Nos parques de Serengeti e Ngorongoro, na Tanzânia e no Quênia, respectivamente, as tribos de pastores, com atividades de pastoreio e queima de pasto, permitiram que os rebanhos e os animais selvagens coexistissem, criando uma paisagem que hoje é valorizada pelos conservacionistas. A constituição de parques nacionais e a exclusão dessas tribos levaram à conversão do pasto em arbustos, com impactos negativos sobre os animais herbívoros, que desempenhavam papel fundamental para a diversidade biológica da região.

Aqui temos a inversão da lógica argumentativa vista anteriormente. Ao invés de grupos humanos invadindo parques, a ênfase está na "exclusão" dos primeiros devido à criação dos segundos. Esta mudança de foco faz Diegues enumerar dois casos envolvendo parques na Tanzânia e no Quênia. O interessante desta inversão, porém, é que se desloca a acusação de que "tribos" causam "impactos negativos" devido a uma conduta intrínseca sua (como sugerem Olmos et al., Dourojeanni, Jorge-Pádua, Galetti e Bernardo) para a denúncia de que tais impactos se devem justamente à "constituição de parques". Em suma, excluir populações passa de solução para a causa do problema, os vilões viram vítimas e as vítimas, os vilões.

De fato, os parques citados por Diegues parecem ser tão emblemáticos como os casos Pataxó e Guarani. Azevedo (2002, p. 37), por exemplo, também desloca a questão: "exemplos como o do Parque Nacional de Serengeti, na Tanzânia, que sofreu graves problemas de deterioração do solo com a expulsão de sua população humana [...], demonstram que em muitos casos a expulsão de comunidades tradicionais pode contribuir negativamente para os objetivos de conservação". Sarkar (2000, p. 48) recorre a este mesmo procedimento:

[...] evidências [que] desafiam o pressuposto de que os parques nacionais resultaram em diversidade biológica sustentável também foram ignoradas. Existem os casos em que a exclusão dos humanos foi prejudicial à biodiversidade. Um dos melhores exemplos é o Parque de Serengeti na Tanzânia e no Quênia. [...]. Pesquisas detalhadas mostraram que [...] o pastoreio e as técnicas de queimada criaram e mantiveram a paisagem que hoje é tão valorizada pelos conservacionistas, e que a presença dos pastores não causaria impacto negativo mensurável nas populações de animais selvagens ou na erosão do solo. Porém, começando em 1951, a maior parte da área foi reservada a parques nacionais. Naquela época já era sabido que a ausência humana e a ausência de pastoreio levavam à conversão de pastagem em áreas florestais, que não pode ser usada pelos herbívoros responsáveis pela diversidade da região.

Além de citar "um dos melhores exemplos" (tal como Olmos et al. citam "um dos casos mais desastrosos"), acusar cientistas de ignorar evidências tem claro objetivo de enfraquecer seus argumentos. Além disso, Sarkar interpõe "pesquisas detalhadas" - que "desafiam o pressuposto" que ele quer atacar - para fortificar seu ponto de vista: "a presença dos pastores não causaria impacto negativo mensurável".

Citar exemplos envolvendo povos Massai e áreas prioritárias à conservação é prática recorrente entre interessados em atacar a tese de que populações tradicionais têm impacto deletério nos ecossistemas. Aliás, reforçar impactos sociais negativos que teriam ocorrido após sua remoção neste e em outros parques serve como argumento para acusar diretamente a tese de que presença humana diminui biodiversidade. É o caso do historiador Ramachandra Guha:

[...] o Touring África, membro proeminente do Sierra Club dos Estados Unidos, atacou fortemente, em 1957, os massais por deixarem seu gado pastar nos santuários naturais da África do leste. Ele usou os massais como exemplo de uma tendência pela qual o uso da terra e o aumento da população são fatores mais importantes na destruição da vida selvagem que a exploração industrial. Os massais e seus "rebanhos economicamente inúteis", afirmou, $[. .$.$] à medida que migram para a Serengeti,$ 
trazem o deserto junto, e a vida e os animais se inclinam diante de seus rebanhos (GUHA, 2000, p. 82-83).

Neste artigo, Guha adota mesmo recurso de Olmos et al.: recorre à história, retira dela "exemplos" de "ataques" (em princípio infundados como o descrito acima), para, com isso, traçar uma correspondência sincrônica entre estes exemplos e práticas autoritárias decorrentes da criação de áreas protegidas. Ainda sobre casos africanos, uma espécie animal (elefante) se destaca quando se deseja atacar posições como as de Olmos et al. Arruda (2000, p. 281), por exemplo, argumenta que a retirada de populações tradicionais para criação de UCs

muitas vezes promove maior degradação ambiental. Em muitos países do terceiro mundo tem se elevado o nível de destruição florestal, à medida que a população expulsa passa a ocupar e derrubar novas áreas para moradia. Os que não conseguem ou não querem mudar para novas áreas são obrigados a superexplorar as áreas ainda acessíveis (florestas vizinhas às Unidades de Conservação) [...]. Porém, em certas situações aparecem efeitos paradoxais da aplicação desse modelo de preservação, como, por exemplo, no caso do Tsavo National Park da África do Leste, descrito por Botkin (1990). A política desenvolvida pela administração do parque para proteger e controlar a população de elefantes provocou uma séria deterioração da terra no interior dos limites da área. Porém, o entorno habitado pelas comunidades humanas expulsas permaneceu florestado e preservado.

Em síntese, como Olmos et al., Galetti, Bernardo e Dourojeanni, Diegues, Sarkar, Guha, Azevedo e Arruda citam diferentes exemplos, situações e casos, só que usados com finalidades contrárias. Enquanto os primeiros seguem tal procedimento para reforçar seu ataque às populações tradicionais e, por tabela, defender áreas protegidas, os segundos o fazem para fortalecer seu ataque à criação destas mesmas áreas quando feitas à revelia dos interesses das populações tradicionais que as habitavam originalmente. Ainda sobre "casos exemplares" e "efeitos paradoxais", outro artifício é reforçar hipóteses de autores aliados para fortalecer nosso ponto de vista. Neste caso, quanto mais citado na literatura e respeitado por seus pares, melhor; se tiver fama de produzir pesquisas rigorosas e sérias, também ajuda; se não for próximo de quem o está citando, ainda melhor, pois garantiria, perante alguns, isenção; e se for um cientista visto como aliado do inimigo, o efeito poderá ser arrasador. Se não, vejamos.

Azevedo (2002, p. 33) arregimenta cientista de peso para auxiliar sua argumentação sobre o que é visto por alguns cientistas praticamente como uma heresia: "Balée (1992) vai ainda mais longe, sugerindo, ao verificar que a diversidade da floresta secundária tende a alcançar a da primária, que a atividade humana contribui para o aumento da biodiversidade". Diegues (2000, p. 38) adota mesma tática ao se referir a um pesquisador inglês já falecido, mas conhecido por seus estudos sobre populações tradicionais: "são relevantes os trabalhos de Posey (1987), nos quais atesta que, ao lado de espécies domesticadas-semidomesticadas, os Caiapó usualmente transplantam várias espécies da floresta primária para os antigos campos de cultivo, ao longo de trilhas e junto das aldeias, formando os chamados 'campos de floresta"'. Menciona a seguir o mesmo autor citado por Azevedo: "Balée (1992a; 1992b) demonstra que a floresta secundária tende a alcançar a primária em diversidade ao longo do tempo, o que pode ocorrer em menos de oitenta anos. A diversidade em número de espécies entre as duas florestas é semelhante: 360 na secundária e 341 na primária". E para fortalecer sua tese cita ainda que

Brown \& Brown (1992) [...] afirmam que o modelo de uso dos recursos naturais de baixa intensidade, desenvolvido pelas populações extrativista e indígenas, frequentemente resulta num mínimo de erosão genética e num máximo de conservação. Ainda que a densidade populacional seja geralmente inferior a $1 \mathrm{hab} . / \mathrm{km}^{2}$, ela pode tornar-se dez vezes maior se o uso dos recursos naturais for cuidadosamente planejado, aproximando-se do uso feito pela agricultura camponesa (DIEGUES, 2000, p. 39).

Em outro momento, além de citar estudos de Balée, Diegues arregimenta outro forte aliado, o mexicano Gómez-Pompa, cujos estudos sobre manejo de recursos naturais por populações locais têm sido bastante difundidos na América Latina9:

\footnotetext{
${ }^{8}$ Aqui deve haver erro de digitação, trocando-se os valores encontrados entre as florestas primária e secundária.

${ }^{9}$ Aliás, se Diegues é um dos autores mais citados no Brasil quando se fala em populações tradicionais, na América Latina a referência a este pesquisador é mais do que obrigatória, sendo, portanto, aliado de peso devido ao status que possui perante seus colegas (Dourojeanni e Jorge-Pádua, 2001, por exemplo - ver citação na próxima página -, mesmo dele discordando, reconhecem que este autor faz "pesquisas sérias").
} 
[...] estudos recentes (Balée, 1988, 1992a; Gómez-Pompa, 1971, 1972 e outros) afirmam que a manutenção e mesmo aumento da diversidade biológica nas florestas tropicais está relacionado intimamente com as práticas tradicionais da agricultura itinerante dos povos primitivos [...]. Vários estudos dessa série de sucessões já existem e, em muitos casos, tendem a concordar que a agricultura itinerante tem sido um meio natural para usar propriedades regenerativas da floresta úmida em benefício do homem (Gómez-Pompa, 1972) [...]. Se estas hipóteses vierem a ser comprovadas, e muitos estudos recentes apontam nessa direção (Oliveira, 1992), é inevitável repensar o conceito de "florestas naturais" e sua modalidade de conservação mediante unidades de conservação onde se proíbe a ação da agricultura itinerante como ainda hoje é praticada por populações indígenas e outras tradicionais: seringueiros, ribeirinhos, caiçaras (DIEGUES, 2000, p. 37)

Por fim, Arruda (2000, p. 284) reúne numa mesma e rápida passagem de seu artigo, além de um cientista brasileiro, os três pesquisadores estrangeiros citados por Diegues:

[...] estudos recentes (Gómez-Pompa, 1990; Posey, 1986; Balée, 1988, 1989, 1993 e outros) potencializam o conhecimento acumulado anteriormente no campo da etnobiologia (Ribeiro, 1986), e indicam que a variabilidade induzida pelo homem no meio ambiente tropical [...] favoreceu e favorece a diversidade biológica e o processo de especiação. Em outras palavras a floresta "primária" tal com a conhecemos coevoluiu juntamente com as sociedades humanas e sua distribuição pelo planeta.

Se os estudos de caso de Galetti, Bernardo e Olmos servem de munição para robustecer hipóteses gerais, o mesmo ocorre, no sentido contrário, com pesquisas de Balée, Gómez-Pompa, Brown e Brown. Todas, depois de concluídas, viraram artilharia pesada para cientistas (como Diegues, Arruda e Azevedo) usarem na guerra discursiva em curso. Ao adquirirem caráter instrumental, tais estudos não só "potencializam" conhecimentos, como lembra Arruda, mas também aumentam o efeito discursivo destes quando imersos numa controvérsia.

O risco desta estratégia é que é sempre possível atacar citações feitas visando refutar, ainda que indiretamente, o autor original. Como alerta Latour (2000, p. 63), "embora seja prático incorporar referências que possam ajudar a fortalecer uma posição, também é preciso atacar as referências que possam opor-se explicitamente às suas teses". Em suma, atacar um aliado do adversário ajuda a enfraquecer a retaguarda deste. Assim, se Arruda, Diegues e Azevedo estão alicerçados no que diziam, entre outros, Balée, Gómez-Pompa e Posey, criticar estes significa contestar, neutralizar ou enfraquecer a argumentação daqueles. Dourojeanni e Jorge-Pádua (2001, p. 180 e 188) adotam tal manobra ao criticarem estudos de Gómez-Pompa:

[...] a partir de pesquisas sérias, embora muito focais, do mexicano Gómez-Pompa (Gómez-Pompa et al, 1972; 1987; Gómez-Pompa e Kaus, 1992), entre poucos mais, se criou a teoria de que o homem [...] é um fator de diversificação genética. [...] demonstrar que a presença e as atividades humanas não têm impacto negativo sobre a natureza é como pretender tapar a luz do sol com a mão. As provas do impacto humano são contundentes e não excluem sequer as mais sofisticadas formas de manejo sustentável já inventadas. A bibliografia sobre este tema é enorme e inclui, entre outros autores, os mesmos cientistas que os inimigos das UCs de uso indireto citam para defender suas teses, entre eles Gómez-Pompa [...].

Já Dourojeanni (2001, p. 91) serra suas fileiras diretamente contra os alicerces dos "cientistas inimigos das UCs de uso indireto":

[...] hay miles de opiniones desde completamente divergentes hasta levemente divergentes entre los científicos. Pero existe uma dilatada media que es universalmente aceptada como la más probable, mientras no se demuestre lo contrario. En ese sentido, por ejemplo, las interpretaciones de Diegues (1996) y otros sobre las teorias del aislamiento, sobre el impacto benéfico de la intervención humana para la biodiversidad, sobre el tamaño de las muestras ecológicamente representativas etc., corresponden al segmento de la curva normal que cae completamente fuera de la media. Las teorias del proprio Gómez-Pompa y asociados $(1972,1992)$, cuándo aplicadas fuera de su contexto, como es tan frecuente, son consideradas uma excentricidad en los medios científicos.

Apesar de reconhecer que há variabilidade "entre los científicos", há uma dupla tática de defesa e de ataque. De 
defesa ao enfatizar "a média" aceita "como mais provável" (posição do autor); de ataque ao criticar "las teorias" que sustentam a trincheira adversária. Aqui, Dourojeanni segue procedimento identificado por Latour (2000): enfraquecer tanto os inimigos como seus aliados, só que com uma sutileza: ao final, coloca um autor de peso (Gómez-Pompa) contra um inimigo seu (Diegues).

Por outro lado, o argumento de Dourojeanni aponta para a flexibilidade que cientistas possuem para realçar ou não um ou outro aspecto. Percebam que sua defesa é feita através de uma observação recorrente entre seus críticos. Se, no caso de populações tradicionais, os textos que publica possuem forte ênfase universalizante e, portanto, tendem a não considerar circunstâncias mais localizadas, para o caso das teorias de Gómez-Pompa "e associados" o autor as contesta dizendo que, justamente, "cuándo aplicadas fuera de su contexto [...], son consideradas uma excentricidad". Ora, tal ênfase (no particular) é recorrente entre aqueles que, contrariamente a Dourojeanni, relativizam o rótulo "depredadores ambientais" conferido às populações tradicionais a partir de casos e exemplos pontuais ${ }^{10}$.

Voltando à crítica às referências, procedimento parecido ao adotado por Dourojeanni e Jorge-Pádua (2001) pode ser visto em Olmos et al. (2001), os quais atacam diretamente Balée e Gómez-Pompa e Kaus, mas visando atingir, de fato, Diegues:

[...] a presença de espécies vegetais aparentemente restritas a antigos terrenos cultivados e ausentes na floresta "primária" circundante (Gómez-Pompa e Kaus 1992, Balée 1992a, 1992b, 1993) tem sido usada como argumento de que agricultura de coivara aumenta a biodiversidade e a prática deve ser mantida ou espécies serão perdidas (Diegues, 1996). No entanto, nenhuma espécie surge por geração espontânea [...]. A agricultura de coivara não gera biodiversidade no sentido de criar espécies, como sugerido pela retórica de alguns autores. Na realidade, em áreas limitadas ela provavelmente causa sua perda [...]. O que a agricultura de coivara faz é criar associações de espécies já existentes que imitam aquelas geradas por fatores naturais e criar algumas associações novas (Ibid., p. 285-286).

Como vimos, Balée e Gómez-Pompa, citados por Diegues, Arruda e Azevedo, compõem dois dos principais pilares a sustentar seus pontos de vista, sendo suas ideias, como dizem Olmos et al., "usadas como argumento". Assim, nada mais eficaz do que criticá-los visando desacreditar suas teorias para, com isso, minar tal sustentação. Por outro lado, tanto Dourojeanni e Jorge-Pádua quanto Olmos et al. adotam a todo instante este mesmo artifício.

Táticas menos ortodoxas podem ser combinadas com casos documentados e citações de outros autores, como usar reportagens jornalísticas para ilustrar um argumento. Dourojeanni (2001, p. 83) cita um “ejemplo: durante los dias en que se escribió esta nota surgió outro escândalo, referido a participación de indios, en eso caso los Kaiapó del sur de Pará, en la explotación ilegal de caoba en su propia reserva, en asociación com madereros ilegales". Embora a evidência seja fortalecida por se tratar de reportagem recente feita no instante em que o autor "escrevia esta nota", neste caso o poder de fogo é menor, pois há o inconveniente de a fonte não ser científica. O mesmo ocorre com o uso de observações pessoais sobre eventos chocantes, caso do relato de Olmos et al. (2001, p. 295) sobre Guaranis do Parque Nacional do Superagui: enquanto "um cacique chegou a ser preso com cinco papagaios destinados ao tráfico, sendo liberado após pagar fiança [...], os Guarani da aldeia Krukutu [...] instalam suas armadilhas. Uma destas, instalada para 'pegar veado', matou uma suçuarana (Puma concolor) incorporada ao Museu de Zoologia da Universidade de São Paulo (F.O., obs. pess.)".

Já documentos oficiais (tais como "laudos") possuem, sem dúvida, maior potência (enquanto evidência) do que notícias de jornal e observações pessoais, já que, em tese, seriam produzidos por pessoas pertencentes a instituições com maior grau de isenção. Assim, para corroborar seus pontos de vista, Galetti et al. (2004, p. 249-250) afirmam:

\footnotetext{
${ }^{10}$ Em texto anterior (GERHARDT, 2007), discuto essa questão a partir de um evento ocorrido ao entrevistar um engenheiro florestal. No caso da ideia de aumento de biodiversidade, divergências podem ocorrer devido a desencontros compreensivos em que o ponto de partida epistemológico e a finalidade da argumentação se dão em esferas diferentes, comprometendo a interlocução devido ao uso de sistemas compreensivos distintos. Na ocasião, enquanto realçava contextos particulares de uso da vegetação comuns a vários grupos rurais, meu colega enfocava perda de biodiversidade por ação humana em termos de número absoluto de espécies. Para ele, biodiversidade seria um conceito universal aplicável a toda biota planetária, sendo sua argumentação guiada por critérios biológicos válidos para qualquer situação. Já no meu caso a ênfase recaía sobre a possibilidade de aumento da quantidade de espécies em termos comparativos, isto é, se o número relativo de espécies de regiões geográficas distintas poderia ser ampliado via interferência humana. Enquanto minhas referências não estavam ligadas a conceitos como ecossistema e sucessão natural, meu interlocutor não considerava a possibilidade de incluir ações antrópicas a partir da ecologia ecossistêmica, pois o uso de modelos biológicos torna-se problemático quando entram em cena fatores socioculturais.
} 
[...] uma avaliação feita pelos técnicos do Instituto Florestal mostrou que o número de porcos-do-mato (queixadas e catetos) caçados pelos índios em 1995 (pelo menos um indivíduo/semana) era três vezes superior à taxa de desfrute sustentável [...], além de ter sido observado o abate de cutias, bugios, mãos-peladas e aves maiores como macucos, jacus e jacutingas (Processo SMA/SP 30.367/95). Pôde também ser constatado o corte intensivo de palmeiras jerivá e palmito-juçara, bem como a venda de animais silvestres vivos e carne de pacas, tatus e capivaras pelos índios na cidade de Cananeia (Processo SMA/SP 30.367/95) [...]. Em junho de 2003, um índio foi encontrado com uma espingarda [...] na região do Canudel pela fiscalização do Parque. Isso indica a falta de conhecimento das ONGs que acompanham estes índios, quando negam que estes caçam e que possuam armas de fogo.

Para fortificar a tese dos autores, novamente são trazidos exemplos ("corte intensivo" de palmeiras, "abate" e "venda de animais silvestres" e existência de "espingardas"), no caso, relatados por técnicos do Instituto Florestal paulista (fonte oficial, portanto, que tende a garantir maior credibilidade). Além disso, a abertura de processo na SEMA contra os Guarani confere expressiva força simbólica aos exemplos.

Outro fator de convencimento poderoso reside no uso de dados numéricos já asseptizados pela decupagem estatística e naturalizados através do seu uso tautológico em estudos científicos. Vejamos o caso de Bensusan (2004, p. 70):

[...] estima-se que $86 \%$ das áreas protegidas da América do Sul são habitadas ou têm seus recursos utilizados pelas populações de seu entorno. Muitas dessas áreas foram criadas sob um modelo de exclusão de populações humanas. Algumas tiveram, efetivamente, suas comunidades realocadas em locais fora das Unidades de Conservação, como é o caso da Estação Ecológica de Anavilhanas [...]. Essa estimativa [...] permite vislumbrar a perversidade embutida no modelo de áreas protegidas que exclui populações humanas, ou seja, quem preserva a biodiversidade de suas terras, perde. Isto é, os sacrifícios são distribuídos desigualmente.

O exemplo de Bensusan (o caso de Anavilhanas) tem papel complementar, pois visa ilustrar o que é dito antes e depois de citado. Contudo, há o efeito produzido pela associação entre uma estimativa (" $86 \%$ das áreas protegidas da América do Sul são habitadas ou têm seus recursos utilizados pelas populações de seu entorno") e uma constatação ("comunidades realocadas em locais fora das Unidades de Conservação"). Na prática, esta combinação permite a Bensusan "vislumbrar a perversidade embutida no modelo de áreas protegidas que exclui populações humanas", as quais seriam "quem preserva a biodiversidade".

Porém, lidar com estatísticas pode ser arriscado, pois não há nenhuma que não possua brechas em sua formatação. Sendo as metodologias usadas muito variadas, bastaria olhar com atenção para o modo como foram obtidos os dados ou escolhidos os parâmetros que lhes dão sustentação matemática. É o que faz Milano (2001, p. 28) ao seguir outro conselho de Latour (2000, p. 66): faça o "necessário com a literatura anterior para torná-la o mais útil possível à tese que você vai defender":

[...] a frequente citação da existência de problemas com populações residentes ou intrusões humanas em cerca de $\mathbf{8 6} \%$ das UCs da América Latina (Amend \& Amend, 1992), dissociada de informações relacionadas ao percentual de área em que tais problemas se manifestam, tanto embute uma mentira maniqueistamente utilizada por adversários da conservação, inocentes induzidos ou ideologicamente militantes, quanto tem sido utilizada da modo mais errado possível pelos próprios defensores da conservação [...]. Decorrente informação distorcida e comumente interpretada de forma viciada está a cômoda disposição de muitos técnicos e políticos em aceitar o fato como verdadeiro [...] e não desenvolver estratégias e ações de resolução dos problemas, que na maioria dos casos são factíveis, como provam as histórias fundiárias dos Parques Nacionais do Iguaçu (PR) e das Emas (GO).

Nada mais trivial do que desconstruir estatísticas para, depois, recolocá-las do nosso lado. Como Bensusan (2004), exemplos "do Iguaçu e das Emas" têm caráter complementar. Embora Milano reproduza longa citação da autora (quase uma página), estrategicamente não cita seus comentários sobre "perversidade embutida no modelo de áreas protegidas". De modo prudente, deixa este tema espinhoso de lado para analisar dados objetivos: "problemas com populações residentes em cerca de $86 \%$ das UCs da América Latina". O ataque centra-se na desconstrução desta 
estimativa, a qual "embute uma mentira maniqueistamente utilizada por adversários da conservação", sem contar a desqualificação direta feita a partir da acusação de que quem assim procede seria ou "ideologicamente militante" ou "inocente induzido". A seguir, Milano pode tecer suas críticas, pois "decorrente dessa informação distorcida" é que estaria "a cômoda disposição de técnicos e políticos em aceitar o fato como verdadeiro". Mas o ataque não para por aí. Em trabalho posterior, Milano (2002, p. 201-202) acusa ainda Bensusan (2001) de ter cometido "erros de informação [...] muito graves", de "não conhecer o assunto" que está tratando, de ter "tentado manipular informação em proveito de ideias próprias", sendo que, ao final, após julgá-la como autora de "atitudes inadequadas", a aconselha a não "tentar se fazer passar por conhecedor".

Dourojeanni e Jorge-Pádua (2001) também atacam os dados citados de Amend e Amend (1992) seguindo, ao citar Milano (2000), outro conselho de Latour (2000): "ajude aliados se forem atacados". Acompanhando a linha de raciocínio de Milano, referem-se à mesma estimativa - " $86 \%$ das UCs da América Latina teriam populações no seu interior, como foi afirmado na compilação de Amend e Amend" - para a seguir criticá-la:

[...] essa informação, assumida como verdade absoluta pelos detratores das UCs de uso indireto, foi construída apenas para ter o efeito que teve. Assim, em primeiro lugar ela inclui categorias de UCs nas que é normal ter populações [...]. Segundo, como aponta Milano (2000), a informação dessa estatística não relaciona a população presente na UC com a área da UC impactada por essa população, criando uma enorme distorção, que o autor qualifica diretamente de inverdade. Terceiro, tampouco se faz referência ao número da população presente, tendo sido registrada uma família com o mesmo peso de uma cidade. Quarto, não se qualifica a população presente, no sentido de saber se são habitantes permanentes, temporais ou apenas incursões de caça ou pesca, nem se fala se são habitantes com direitos legais ou, conforme a lei, apenas invasores recentes (DOUROJEANNI; JORGE-PÁDUA, 2001, p. 198).

Ao mesmo tempo em que usam em seu favor o argumento de Milano (2001) - que qualifica o dado citado por Bensusan (2004) como "inverdade" -, os autores fortalecem seu aliado. Primeiro, classificam o dado $86 \%$ como construído para ter o efeito específico de atacar UCs de uso indireto; então, baseados nesta constatação, contra-atacam desmontando a estatística dos Amend ao arrolarem quatro fatores que a enviesariam. Resultado, após este bombardeio, a evidência original citada por Bensusan (2004) acha-se, ao menos, debilitada.

Mas é possível usar outras informações com alto potencial de persuasão, como imagens de satélite e fotografias aéreas. Ladeira (2004, p. 30) menciona tais tecnologias sofisticadas:

[...] o fato, que se preferiu ignorar, é que o reconhecimento dos direitos dos Guarani às terras que ocupam impediu maiores e piores desmatamentos para recentes projetos de desenvolvimento [...]. Também se observa que a regularização fundiária de terras Guarani possibilitou a recuperação da vegetação nativa, como mostram imagens de satélite e fotografias aéreas em extensões ocupadas e reconhecidas para os índios há mais de 10 anos (Araponga, Parque Nacional da Bocaina/RJ, Rio Branco e Aguapeu, PEM/SP, entre outras).

Aqui inverte-se o argumento de Olmos et al. (2001) e Dourojeanni e Pádua (2001). Se estes sustentavam que áreas "invadidas" pela "pátria Guarani” teriam sido vítimas de "um impacto negativo", agora teria sido justamente o fato de ocuparem estas áreas que "impediu maiores e piores desmatamentos"; o mesmo vale para a "regularização fundiária de terras Guarani”, a qual "possibilitou a recuperação da vegetação nativa". Aproximando-se da crítica anterior (tomar "informações como verdades absolutas"), Ladeira acusa seus opositores de ignorarem um fato concreto ("imagens de satélite" e "fotografias aéreas") que atestam sua afirmação sobre "recuperação da vegetação nativa" (e os exemplos dos quatro parques vêm novamente se somar a esta tática). Porém, o mesmo instrumento (imagens de satélite) é usado, com propósito inverso, por Olmos et al. (2001, p. 292):

Pataxó são uma das mais importantes fontes de destruição do patrimônio natural (e da Humanidade) que é o Parque Nacional do Monte Pascoal, como documentado pelas fotos de satélite que mostram o desmatamento da área por eles ocupada. Isto é mais grave considerando que o Monte Pascoal é uma das mais importantes áreas para aves ameaçadas da Mata Atlântica (Wege e Long, 1995) e um dos poucos remanescentes florestais com apenas $0,4 \%$ de floresta intacta (Mendonça, 1994). 
Em apenas cinco linhas, os autores condensam uma espécie de mix tático: juntam às imagens de satélite estudos de outros autores e uma estatística, além de citar a palavra-chave "ameaçadas" (no caso, aves), que energiza o argumento. Latour (2000, p. 85) chama tal artifício de juntar "números, fotos, figuras, nomes ao texto e enlaçá-los bem" de "empilhamento".

Outra arma usada em batalha são relatórios e recomendações de grandes organismos internacionais. Como Olmos et al., Diegues (2000, p. 40) faz uma dobradinha ao trazer para suas fileiras dois poderosos aliados:

[...] trabalhos recentes do Banco Mundial (Cleaver, 1992) apontam na direção da desmistificação das "florestas intocadas" e na importância das populações tradicionais na conservação da biodiversidade. Nas recomendações para o Banco, Bailey afirma: "a composição e distribuição presente das plantas e animais na floresta úmida são o resultado da introdução de espécies exóticas, criação de novos habitats e manipulação continuada pelos povos da floresta durante milhares de anos [...]. A atual biodiversidade existe na África não apesar da habitação humana, mas por causa dela. [...] se excluirmos os seres humanos do uso de grandes áreas florestais, não estaremos protegendo a biodiversidade que apreciamos, mas a alteraremos significativamente e provavelmente a diminuiremos ao longo do tempo".

Além de deslocar a questão, Diegues traz como evidência um relatório patrocinado pelo Banco Mundial (o qual financia diversas áreas protegidas ao redor do planeta) e outro cientista (Bailey) renomado na área. Assim, quem se opuser ao argumento, estará contrariando o tal relatório e o pesquisador citado. Como Dourojeanni (2001), sutilmente Diegues (2000) diz algo como: "olha, não sou só eu que a falar isso, tem gente e instituições importantes comigo".

Mas, antes de prosseguir, recapitulemos alguns tipos de evidências vistas até aqui: exemplos e estudos de caso; referências ao que dizem autores aliados; estimativas, como a exposta por Bensusan (2004), depois desconstruída por Milano (2001); reportagens e notícias impactantes; fórmulas científicas $\left(\mathrm{r}^{2}=0,0003 ; \mathrm{F}=0,02 ; \mathrm{P}=0,86\right)$; relatórios de órgãos oficiais e documentos legais ("laudos" e "processos"); trabalhos de organismos internacionais; imagens de satélite; “observações pessoais". Mas há outros modos de lidar com evidências, visando fortalecer ou enfraquecer pontos de vista, refutar ou reforçar acusações. Vejamos alguns.

\section{Arregimentando aliados, retorsio argumenti $\boldsymbol{e} o$ efeito de deslocamento}

Em Ciência e ação, Latour (2000, p. 53-75) descreve o uso de algumas técnicas argumentativas as quais seguem três diretrizes gerais: 1) "arregimentar amigos", isto é, reunir o maior número de aliados que ajudem a reforçar nossas hipóteses e teses; 2) "reportar-se a textos anteriores", visto que "um fato pode ser transformado em ficção ou uma ficção em fato apenas com o acréscimo ou subtração de referências" (Ibid., p. 58); e 3) ser tomado como referência por textos posteriores. Em outro trecho, Latour (2000, p. 66) sugere ainda: "faça tudo o que for necessário com a literatura anterior para torná-la o mais útil possível à tese que você vai defender; enfraqueça os inimigos; paralise os que não puder enfraquecer; ajude os aliados se eles forem atacados; obrigue inimigos a brigarem uns com os outros".

Manuela Carneiro da Cunha (1999, p. 149), ao indagar "afinal, quem ocupa as áreas de maior riqueza genética, não por acaso, mas porque são produtores de diversidade?", responde em seguida: “são precisamente populações tradicionais". Para além da veracidade ou não da afirmação, neste caso particular a autora está literalmente sozinha: não traz nenhum aliado para ajudá-la a fortalecer a tese de que populações tradicionais seriam "produtore[a]s de diversidade". O que é um risco, pois, conforme Latour (2000, p. 58), um texto "sem referências é como uma criança desacompanhada a caminhar pela noite de uma grande cidade que ela não conhece: isolada, pode acontecer-lhe qualquer coisa". Considerando a ojeriza de alguns colegas a tal alegação, ela poderá ser facilmente atacada, pois está desguarnecida, sem sequer um escudeiro, isto é, sem nenhuma referência amiga a fortalecê-la. Por maior que seja o prestígio de Cunha como pesquisadora, seus capitais simbólico e científico acumulados têm poder de alcance limitado, o que enfraquece o poder persuasivo do argumento usado. Além de um eventual detrator poder reunir evidências que apontem no sentido contrário, a autora poderá ser acusada de tirar conclusões que careceriam de fundamentação ${ }^{11}$.

\footnotetext{
${ }^{11}$ Tal debilidade aumenta se levarmos em conta que capitais simbólicos "consistem no reconhecimento atribuído pelo conjunto de pares-concorrentes no interior do campo científico" (BOURDIEU, 2004, p. 26). Ora, no presente caso, a admissão de eventuais competências dependerá da área de atuação de cada pesquisador
} 
De fato, quando deparamos com uma controvérsia da envergadura desta que estamos lidando, recrutar o maior número de aliados para reforçar argumentos pode ser decisivo. Como visto, Latour (2000) chama tal tática de "arregimentar amigos". Olmos et al. (2001, p. 287), por exemplo, alegam que, "embora encaradas como algo generalizado, atitudes conscientes por parte de 'povos tradicionais' que resultem em padrões de uso sustentável são praticamente inexistentes". Mas, como a afirmação acha-se ainda sem base de sustentação (o que deixaria os autores com a guarda aberta), é preciso dar-lhe credibilidade para, com isso, produzir "efeitos de verdade" (FOUCAULT, 1997) ou, então, "efeitos de realidade" (LATOUR, 1994) ${ }^{12}$. Assim, Olmos et al. (2001, p. 287) logo arregimentam número expressivo de aliados em suas fileiras:

[...] como exaustivamente apontado por vários autores (Redford, 1991, 1992; Peres 1997a; Avard 1993, 1995; Spinage 1998; Whelan 1999; Milano 2000, entre outros) a sustentabilidade na exploração de recursos naturais por "populações tradicionais" é antes regulada pela densidade populacional e deficiência de aparato tecnológico do que por atitudes conscientes ou mecanismos culturais endógenos, em geral a atitude das "populações tradicionais" é inteiramente imediatista, e muitas ainda não possuem o conceito que recursos naturais podem ser finitos e destruídos pelas suas atividades.

Além dos doze cientistas que assinam o referido artigo, estes têm agora ao seu lado mais seis pesquisadores, ou seja, caso deseje discordar do que eles sustentam, terei pela frente, protegendo a retaguarda, um total de 18 pesquisadores. Este procedimento de trazer evidências advindas de estudos já realizados é repetido outras vezes por Olmos et al. (2001, p. 286):

[...] há abundante prova científica de que "comunidades tradicionais" contemporâneas exploram recursos de forma não sustentável e causam perdas de espécies. A caça de subsistência por índios, seringueiros e outros "tradicionais" é uma destas modalidades de uso e há um grande volume de literatura sobre o assunto (p. ex., Peres 1990, 1996, 1997a, 1997b; Sá 2000, Redford 1992, Alvard et al. 1997, Bodmer et al. 1997, Bergazo e Bodmer 1998, Robinson e Bodmer 1999), incluindo obras recentes (Robinson e Redford 1991, Pádua et al. 1997, Robinson e Bebbett 2000). Os resultados mostram que a grande maioria explora pelo menos algumas espécies-presa de forma não sustentável (Ibid., p. 286).

Outra vez, refutar as afirmações acima significa divergir não só de um grupo grande de cientistas (sem contar que há os "et al." em algumas referência citadas, espécie de soldados da reserva que, porém, podem rapidamente ser chamados a entrar em ação), mas de 13 publicações científicas feitas num período relativamente curto de dez anos (pois quanto mais antigo um texto científico, menor sua força). Obviamente, Olmos et al. não são os únicos a usar a tática de citar "grande volume de literatura" para realçar que haveria "abundante prova científica" sobre a tese de que "comunidades tradicionais [...] exploram recursos de forma não sustentável e causam perdas de espécies". Este é o caso de Milano (2002, p. 199):

[...] a questão da possível compatibilidade entre conservação de diversidade biológica e presença humana e uso dos recursos naturais em unidades de conservação é outro mito que, como tal, decorre de deficiências de conhecimento em evolução, ecologia e biologia da conservação por parte daqueles que estabelecem essa questão, ainda que seja apresentado como um novo paradigma de modernidade. Provas evidentes do contrário têm sido apresentadas, entre muitos outros, por Myers (1986), Chagon (1995), Redford (1997), Bodmer \& Penn Jr. (1997), Rocha (1997), Dourojeanni (1997), Margolis (2000), Fernandez (2000) e Ayres et al. (1996), com destaque para os dois últimos.

Além de acusar colegas de se orientarem a partir de "um mito" decorrente de "deficiências de conhecimento" (o que os desqualificaria a falar sobre "compatibilidade entre conservação de diversidade biológica e presença

e, igualmente, do contexto em que são acionadas. Assim, a autoridade que antropólogos detêm para falar sobre interações biocenóticas ou zonas de endemismo tende a ser menor do que a de biólogos; contudo, estes tendem a ter menor legitimidade ao se pronunciar sobre implicações do uso político ou analítico da categoria população tradicional ou sobre cosmologia ecológica Yanomami. Em síntese, cientistas que circulam por disciplinas tangenciais às suas respectivas áreas - ou que delas tenham visão panorâmica - se arriscam a todo o instante "a estar defasados, deslocados, mal colocados, na contramão, com todas as consequências que se possa imaginar" (BOURDIEU, 2004, p. 29).

${ }^{12}$ Sobre ambos os efeitos, ver discussão contida na introdução. 
humana") ${ }^{13}$, Milano arregimenta, para sustentar seu argumento, dez cientistas que teriam "provas evidentes" desta "deficiência". Por outro lado, Milano e Olmos et al. seguem outra advertência de Latour (2000): "ajudar seus aliados". Se tomarmos apenas os autores já citados até aqui, Olmos et al. fazem referência (positiva) direta a Dourojeanni e Milano, sendo que este, como visto acima, também cita o primeiro. Esta ajuda recíproca aparece ainda em outro trecho de Olmos et al. (2001, p. 284) quando citam Fernando Fernandez, especialista em biologia da conservação: “é interessante lembrar a pertinente colocação de Fernandez (2000b) de que 'povos que hoje dizemos que coexistem em harmonia com a natureza coexistem apenas com as espécies difíceis de extinguir, porque as fáceis de extinguir já foram exterminadas há muito tempo"”.

Porém, o mesmo exercício pode ser feito a partir de trechos extraídos daqueles que divergem dos autores citados no parágrafo anterior. Arruda (2000, p. 284), por exemplo, para fortalecer a tese de que "a variabilidade induzida pelo homem no meio ambiente tropical $[. .$.$] favoreceu e$ favorece a diversidade biológica e o processo de especiação", arregimenta em suas fileiras seis estudos realizados por quatro pesquisadores: "Gómez-Pompa, 1990; Posey, 1986; Balée, 1988, 1989, 1993; Ribeiro, 1986”. Já Santilli (2005) constrói seu escudo protetor talvez de olho noutra possibilidade aventada por Latour (2000, p. 59): "ao atacar um texto carregado de notas de rodapé, o discordante terá de enfraquecer cada um dos outros textos". Após afirmar: "já há diversos estudos que mostram que são práticas, inovações e conhecimentos desenvolvidos por povos indígenas e populações tradicionais que conservam a diversidade biológica de nossos ecossistemas" (Ibid., p. 195), para dar credibilidade à afirmação, a autora arregimenta, em nota de rodapé, pesquisas feitas por Diegues e Arruda (2001) e dois outros estudos de Balée (1993). Além de ajudar aliados que, como vimos, estão sob a mira cerrada de seus oponentes, tal artifício é mais do que compreensível, pois Santilli poderá vir a ser acusada, como o faz Adams (2000, p. 226) em relação a Diegues e Nogara (1994), de fazer afirmações "levianas" que "carecem de fundamentação sólida" ou, com
Milano (2002, p. 201), de lidar com "erros de informação" ou que "não conhece o assunto".

De fato, segundo Cristina Adams (2000, p. 226), Diegues e Nogara (1994) teriam feito "afirmações sobre populações caiçaras [...] de forma leviana, com fundamentação teórico-metodológica deficiente ou falta de embasamento empírico". Ao final, conclui ainda que a maior parte dos trabalhos sobre comunidades caiçaras "não possui um caráter científico", visto que a "investigação realizada não foi imparcial, mas partiu de conclusões preconcebidas [...] para buscar justificativas para posicionamentos político-ideológicos" (Ibid., p. 261-262). Ora, embora Adams tenha posição frontalmente contrária à visão de Olmos et al. (ver GERHARDT, 2008), este tipo de crítica a autores como Diegues e aliados acabou produzindo munição para estes 12 autores, para Dourojeanni e Jorge-Pádua (2001) e para vários outros pesquisadores, sendo posteriormente citada por eles com o propósito de reforçar a tese sobre o "perigo" das populações tradicionais à proteção da biodiversidade ${ }^{14}$.

Voltando à tática de arregimentar aliados, vemos que, caso se deseje evitar ou dificultar questionamentos posteriores, referenciar nossas afirmações pode ser decisivo, pois, caso contrário, a pessoa poderá ver seu argumento ser visceralmente destroçado. Mas ainda assim é possível rastrear a literatura visando achar brechas nas fileiras inimigas, o que não farei por motivos de espaço. Porém, sobre esta possibilidade, Latour (2000, p. 59) comenta que talvez "empilhar montes de referência não seja suficiente para se tornar forte se o oponente for ousado". Assim, se este for atrás de "cada referência e procure comprovar até que ponto elas correspondem à tese do autor", poderá descobrir "muitas referências citadas indevida ou incorretamente" (que "muitos artigos a que o autor alude podem não ter relação nenhuma com sua tese e estar ali só para impressionar e [que] outras citações podem estar presentes, mas pela simples razão de sempre estarem presentes nos artigos do autor".

Vejamos agora o que chamei de efeito deslocamento, o qual remete à possibilidade de alterar quem está sendo alvo de ações destrutivas. Assim, ao invés de indagar: "qual

\footnotetext{
${ }^{13}$ A alusão a "mitos" que guiariam o trabalho de especialistas constitui tática recorrente nas disputas ligadas à controvérsia aqui tratada, porém, sua importância é tanta que optei por abordá-la em artigo específico. Sobre sua instrumentalização no debate sobre áreas protegidas e populações locais, ver tópico de minha tese “A guerra dos mitos" (GERHARDT, 2008).

${ }^{14}$ Tive oportunidade, em 2007, de perguntar à própria Cristina Adams o que achava de apropriações como estas. Ao comentar que seu livro estaria sendo usado contra a posição pró-populações locais, esta respondeu: "Sei, já me deparei com alguns desses personagens e fiquei meio assustada, porque na verdade eles retiram trechos, é uma leitura parcial. De fato, já vi isso e não me agrada. Mas acho que quem for ler o livro na verdade tem material para os dois lados. [...] porque acho que a discussão no fundo era e ainda é política, não tinha base científica, era uma discussão realmente de que lado você está. Se você está do lado das populações você descobre isso e isso ou, se está do lado da natureza, enfim, sei lá, descobre outros argumentos”.
} 
o impacto das populações tradicionais sobre a biodiversidade?", poderia propor a questão: “quais os impactos das políticas de proteção à biodiversidade sobre a qualidade de vida das populações tradicionais?". Aqui há a inversão qualitativa da controvérsia, visto que potenciais vítimas não são mais espécies, florestas, ecossistemas ou biomas, mas populações tradicionais. Invertida a questão, basta sair em busca de casos na literatura que comprovem nossas afirmações. Santilli (2005, p. 156), por exemplo, cita alguns já nossos conhecidos envolvendo etnias africanas:

[...] um dos questionamentos éticos que se faz em relação à criação de unidades de conservação diz respeito às discriminações sociais engendradas por políticas de conservação que desconsideram o papel das populações tradicionais na conservação de seus habitats naturais e simplesmente promovem a sua expulsão para criar unidades de conservação. Tal prática se baseia em um total desrespeito [...]. Vistas como um entrave e uma ameaça à conservação, tais populações tradicionais foram, em muitos casos, simplesmente expulsas de suas terras, como ocorreu com os Masai, população tradicional do Quênia, que tiveram que deixar suas terras para a implantação de um parque nacional. Outro parque nacional criado com o sacrifício da expulsão de populações tradicionais foi o Kruger, na África do Sul. No Brasil, exemplo de unidade de conservação implantada à custa de retirada de populações tradicionais é a Estação Ecológica de Anavilhanas, no Amazonas.

Eu mesmo já utilizei, ainda que disfarçadamente, exemplos como os citados acima:

[...] não é o caso aqui de listar os inúmeros estudos de caso que abordam a dramaticidade social e os efeitos perversos para diversas populações locais atingidas pela criação de UCs nas últimas décadas. Porém, para leitores não familiarizados com o tema, indico quatro pesquisas emblemáticas devido à amplitude da violência cometida e por serem relativamente recentes [...]. São elas: Brustolin (2003), que faz uma análise da história dos conflitos envolvendo a criação do Parque Nacional dos Aparados da Serra/RS; Campos (2001) e Nunes (2003), cujas dissertações discutem as transformações ocorridas na vida de caiçaras com a criação da Estação Ecológica Jureia-Itatins/SP; e Ioris (2000), a qual resgata a história dos conflitos gerados pela criação da Floresta Nacional Tapajós/PA (GERHARDT, 2007, p. 23).
Relendo este trecho, percebi nele sutil artifício linguístico: as referências (Brustoli, Nunes, Campos e Ioris) combinadas com exemplos (Tapajós, Aparados da Serra, Jureia-Itatins) são fortalecidas justamente pela ausência de outras referências. Quando antecipo: "não é o caso aqui de listar", e, logo depois, completo a frase com expressões impactantes ("dramaticidade social", "amplitude da violência" e "efeitos perversos"), este recurso retórico potencializa o que é dito em seguida. Assim, não citar "inúmeros estudos de caso que abordam" a violência por que teriam passado "populações locais atingidas por áreas protegidas", paradoxalmente, aumenta o efeito discursivo dos quatro casos citados.

Marcus Colchester, outra referência recorrente na literatura, também traz exemplos para criticar o conservacionismo. Percorrendo mais de um século e cinco continentes, este antropólogo começa citando o segundo parque nacional moderno criado depois de Yosemite:

[...] em 1872 os índios que viviam na região [...] eram demônios vermelhos rastejantes. Os residentes Shoshones de Yellowstone foram então expulsos, de "boa vontade", mas dados subsequentes sugerem que houve violentos conflitos entre as autoridades do parque e os Shoshones: cerca de trezentos índios foram mortos em confrontos em 1877. Um dos exemplos mais grotescos desse processo foi documentado por Colin Turnbull [...], que descreve as consequências da expulsão dos povos coletores-caçadores, chamados Iks, de seus territórios de caça para o estabelecimento do Parque Nacional de Kidepo, em Uganda. Obrigados a adotar a agricultura de subsistência nas terras altas em volta do Parque, os Iks sofreram fome prolongada levando ao colapso total da sociedade e ao desaparecimento de seus valores [...]. O parque Nacional de Dumoga-Bone, no Sulawesi, Indonésia [...] exigiu a expulsão do povo nativo Mongondow, forçado a morar nas montanhas [...]. Parques nacionais para a proteção dos gorilas, no Zaire, Uganda e Ruanda levaram à expulsão dos pigmeus Batwas [...]. Reassentamentos forçados não são coisa do passado. Em Uganda, expulsões em massa de camponeses e habitantes das florestas aconteceram durante a implementação de um [...] corredor de vida silvestre entre a Reserva Florestal de Kibale e o Parque Nacional Rainha Elisabeth. [...] cerca de 30.000 nativos da Reserva Kibale e do corredor de fauna foram expulsos, sem notificação anterior, levando à violação graves dos direitos civis, incêndio, matança de gado, empobrecimento em massa e morte de pessoas (COLCHESTER, 2000, p. 232-234). 
Já Azevedo (2002) traz uma série de casos para comprovar que deslocamentos de grupos humanos implicariam "alto custo social". Segundo o autor,

problemas decorrentes da criação de áreas protegidas são amplamente documentados e se relacionam na maioria dos casos à necessidade de remoção e deslocamento de populações humanas das áreas a serem transformadas em UCs. Exemplo deste processo é a expulsão dos iks, tradicional povo de coletores-caçadores expulsos de seus territórios ancestrais em Uganda para a criação do Parque Nacional de Kedepo, e que [...] sofreram problemas de fome prolongada e desaparecimento de seus valores tradicionais [...], além de adotarem práticas como caça ilegal, mendicância e prostituição para sobreviver (Turnbull, apud Colchester, 2000). Outros exemplos incluem os mongondow, da Indonésia [...] e os pigmeus batwas do Zaire, Uganda e Ruanda, expulsos de sua terra para a criação de parques de proteção aos gorilas (AZEVEDO, 2002, p. 37).

Especificamente sobre "casos" ocorridos no Brasil, Arruda (2000, p. 282) traz "outra situação ilustrativa da ‘invisibilidade' destas populações”:

[...] o caso da Estação Ecológica do Iquê, no Mato Grosso, criada em 1981, totalmente dentro do território do povo indígena enauenê-nauê. Este povo, contatado em 1972, era na ocasião totalmente desinformado sobre as características e a dinâmica social da sociedade envolvente, vivendo séculos de forma autônoma e independente na região. A estação ecológica do Iquê é uma [UC] de papel, mas sua existência provocou atraso de dez anos na demarcação da área indígena (só realizada em 1995) e contribuiu para o agravamento dos conflitos com outros segmentos sociais pela indefinição legal dos limites da área (neste intervalo foram mortas cerca de nove pessoas em ocasiões diversas). No caso do Brasil, a recorrência da criação de unidades de conservação superpostas a áreas indígenas são um exemplo da incorreção dessas superposições e da cegueira generalizada em relação à existência destas populações.

Entre os pesquisadores brasileiros, Diegues (1996) talvez seja aquele que mais use a tática de apontar casos em que teriam sido cometidas agressões ou realizadas ações violentas contra populações tradicionais devido à criação de UCs. Cito rapidamente dois deles. Um teria se passado numa UC já nossa conhecida e outro noutra localizada no estado do Mato Grosso:

[...] no Parque Estadual da Ilha do Cardoso, litoral sul de São Paulo, criado em 1962, vivem centenas de famílias, muitas das quais deixaram a terra natal pela perseguição da fiscalização. [...] em 1974 ainda havia centenas de famílias na área quando foi elaborado o plano de manejo pelo Instituto Florestal [...]. Nem ao menos mencionou a existência das comunidades caiçaras [...]. Se no Estado de São Paulo a população tradicional é tolerada, nem sempre ocorre o mesmo em outros estados, como a situação descrita por Sonoda (1991), na Estação Ecológica de Serra das Araras, no Mato Grosso, da qual cerca de 17 famílias foram expulsas (DIEGUES, 1996, p. 138).

Já o segundo caso refere-se ao que teria ocorrido em uma reserva ecológica do Pará:

[...] em 1979, o IBDF (depois Ibama) criou a Reserva Ecológica de Trombetas [...]. Como analisam Acevedo e Castro (...), "vinte e cinco famílias, residentes no Lago Jacaré, foram ameaçadas de expulsão pelo IBDF, caso não desocupassem a área da Reserva [...]". O Ibama, auxiliado pela Polícia Federal, retirou dos moradores seus instrumentos de caça e pesca, assemelhando-se à repressão das empresas mineradoras implantadas na área [...]. A implantação da Reserva Ecológica na margem esquerda do Trombetas e a criação posterior, em 1989, da Floresta Nacional na margem direta tornaram inviável o modo de vida dos negros libertos de Trombetas (DIEGUES, 1996, p. 144).

Nos últimos trechos reproduzidos, a vantagem anterior dos que trabalham com a tese de que populações tradicionais têm pendor intrínseco para destruir recursos naturais se inverteu, pois, em uma disputa qualquer, tenderá a ficar em vantagem (ainda que provisória) aquele que está em posição de ataque, isto é, quem acusa e não o acusado. Se antes órgãos como SEMA e Instituto Florestal eram responsáveis pela denúncia de ações ilegais, agora IBAMA e Polícia Federal são acusados de serem agentes repressores que "tornaram inviável o modo de vida" de certos grupos sociais. De "depredadoras dos recursos naturais", "fonte de destruição do patrimônio natural", "matadoras" de 
"suçuaranas", protagonistas de "escândalos" como "tráfico" de animais silvestres, detentoras de "práticas insustentáveis", de terem "papel importante no desaparecimento da megafauna", de causarem "extinção de espécies", "exterminarem" "aves do mundo", de, como sustenta Fernandez (2004, p. 46), serem responsáveis pela "perda" de "seres maravilhosos" e "rasgarem passagens grandiosas" de "um poema que era perfeito", populações tradicionais deixam de ser arautos de um "genocídio ecológico" para se tornarem vítimas das estratégias de preservação adotadas ${ }^{15}$.

A partir dessa inflexão narrativa, são políticas de conservação que originam "exemplos mais grotescos"; causam "expulsão de povos"; acarretam "sofrimento e fome prolongada"; determinam "colapso total de sociedades" e "desaparecimento de seus valores"; levam índios a serem mortos; produzem situações de "dramaticidade social", "expulsões em massa", "reassentamentos forçados"; atrasam a "demarcação de áreas indígenas" e "contribuem para o agravamento dos conflitos com outros segmentos sociais"; provocam "violações graves dos direitos civis, incêndio, empobrecimento em massa e morte"; estimulam o "desaparecimento de valores tradicionais"; "promovem a expulsão" de populações tradicionais de suas terras; estimulam "discriminações sociais" e a conflagração de "violentos conflitos", propugnam "práticas" "baseadas em total desrespeito" a seus modos de vida. Enfim, são os defensores da biodiversidade que agora são acusados de serem repressores e "exemplo de incorreção" - ao contrário da "incorreção" sugerida por Olmos et al. (2001), para os quais populações tradicionais seriam uma "crescente ameaça" -, de protagonizarem uma "cegueira generalizada em relação à existência destas populações", de desencadear "efeitos perversos" e de "retirar moradores" que tiveram que "deixar sua terra natal pela perseguição da fiscalização". Se antes pairava no ar a denúncia de que populações tradicionais estariam usando recursos de modo ecologicamente inadequado, agora vem à tona a "perversidade" por trás do discurso dos que insistem na necessidade de retirar populações de UCs de proteção integral. Agora acusadores, acuados, precisarão se defender, o que, obviamente, não é uma posição confortável.

Mas, ainda assim, é possível achar saídas adotando táticas evasivas, reinvertendo e redeslocando a questão ou mesmo partindo para o ataque frontal. Analisando questionamentos sobre UCs de uso indireto, Dourojeanni e Jorge-Pádua (2001) e Dourojeanni (2001) constroem toda uma contra-argumentação às acusações vistas acima, sistematizando-as na forma de três tipos de argumentos contrários a estas UCs: "argumentos científicos", "argumentos político-administrativos" e "argumentos de tipo social". Nos últimos estariam

[...] três linhas principais: (i) o caráter antissocial das UCs de uso indireto [...]; (ii) a afirmação, completamente gratuita, de que as autoridades têm usado ou usam [...] a força para expelir as populações locais das UCs de uso indireto; e (iii) que as UCs de uso indireto são estabelecidas sempre contra os interesses da população local e/ou que esta está sempre marginalizada dos benefícios (Ibid., p. 198).

A primeira tática adotada é menos eficiente do que as demais; todavia, nem por isso deixa de produzir efeitos: simplesmente, negar as acusações. É o que faz Dourojeanni (2001, p. 67): “en el pasado, la creación de UCs en América Latina no há generado grandes conflictos con la sociedad afectada". A seguir, o autor enumera as razões que o levaram a esta afirmação:

[...] porque en este continente se han aplicado estratégias poco ortodoxas [...] para evitar conflictos. Merecem mención las seguientes: 1) todos os gobiernos han evitado, hasta donde fue posible hacerlo, crear UCs en las áreas ocupadas o usadas [...]; (3) cuándo no fue posible ubicar áreas ecológicamente valiosas sin presencia de pobladores, muchas vezes se aceptó esa presencia y el uso de los recursos naturales en zonas definidas en su interior, incluso en parques nacionales; [...] (5) en ningún caso documentado, en la historia de América Latina, se ha usado la violencia para sacar de una UC a pobladores tradicionales originariamente presentes en la área.

Dourojeanni faz uso do que Ducrot (1976) chamou de "operadores argumentativos", como as expressões "grandes", "todos", "muchas" e "ningún". Conforme Koch (2004, p. 30), “são justamente essas 'palavrinhas' as

\footnotetext{
${ }^{15}$ Com exceção do autor citado, todas as demais expressões deste e do próximo parágrafo foram retiradas (com uma ou outra alteração no tempo verbal ou na concordância de gênero e número das palavras) de publicações citadas no presente artigo.
} 
responsáveis, em grande parte, pela força argumentativa de nossos textos" ${ }^{\text {". }}$. Além de sustentar não haver nenhum caso documentado de uso de "violência para tirar populações tradicionais de uma UC", Dourojeanni opta por enfatizar, em contraponto:, o trabalho criterioso dos governos ao criarem UCs (afinal, "todos" teriam evitado "criar UCs em áreas ocupadas"): o cuidado com que isso foi feito (que surge na frase "até onde foi possível fazê-lo"); e sua flexibilidade para lidar com situações distintas (presente na frase "quando não foi possível [...] se aceitou essa presença"). Neste último caso há a ênfase no que seria a regra ("muchas vezes"), sendo as demais situações meras exceções. Por fim, no caso de eventuais problemas, estes não teriam "gerado grandes conflitos". Sintetizando os argumentos de Dourojeanni: a criação de UCs não gerou conflitos relevantes; todo esforço possível foi feito para evitá-los e, quando ocorreram, resolveu-se a situação do melhor modo possível.

Também é possível contornar acusações como as vistas em Arruda (2000), Santilli (2005) e Azevedo (2002) questionando a representatividade numérica dos casos citados. Dourojeanni e Jorge-Pádua (2001), ao comentarem “a afirmação, completamente gratuita, de que autoridades têm usado [...] a força para expelir as populações locais das UCs de uso indireto", rebatem-na sustentando que tal afirmação, apesar "de discutível no caso africano",

não guarda relação alguma com a realidade da América Latina e do Caribe, onde a grande maioria das áreas estritamente protegidas foi escolhida para evitar conflitos com as populações indígenas e tradicionais. Os conflitos, se existem, são em sua maioria artificialmente criados ou ampliados por partes interessadas [...]. É óbvio que a mera existência de uma área protegida pode gerar conflitos [...]. Porém, a maior parte desses conflitos é grosseiramente exagerada na literatura, que se baseia na argumentação de entrevistas, frequentemente tendenciosas, com a população a priori classificada com afetada (DOUROJEANNI; JORGE-PÁDUA, 2001, p. 200).
Apesar dos autores já admitirem a possibilidade de haver conflitos (embora a coloquem em suspensão através do aposto "se existem"), novamente ressaltam o que seria a regra geral: "a grande maioria das áreas" e "a maior parte desses conflitos". Como casos africanos parecem difíceis de ser simplesmente negados, nem aí se rendem, sugerindo que o uso da força nestes casos seria, ao menos, "discutível" (portanto, a ser comprovado). O contra-ataque vem ainda através dos operadores argumentativos "completamente", "grosseiramente", "frequentemente". O primeiro aponta o caráter infundado da alegação de uso da "força para expelir as populações locais de UCs"; o segundo reforça que haveria "exagero" na identificação de conflitos; e o terceiro ataca diretamente os atacantes ao refutar a "argumentação" das "partes interessadas" acusando-a de "tendenciosa" por se basear em entrevistas com pessoas diretamente envolvidas.

Outra manobra evasiva a ser adotada quando se está sob ataque é seguir um dos "estratagemas dialéticos" de Schopenhauer (1997, p. 160): para não responder diretamente a uma questão e, de quebra, neutralizá-la, abre-se uma tangente, um desvio, contrapondo-a a um fato alternativo ao que está sendo debatido. Vejamos dois exemplos. Milano (2001, p. 29) alega:

[...] é evidentemente errônea a interpretação que tem sido dada à questão de eventuais disputas, que nem deveriam ocorrer, entre interesses conservacionistas da criação de unidades de conservação e populações locais.

Pessoas e comunidades de todas as origens e índoles são sistematicamente deslocadas de suas terras originais [...] em razão de grandes e destrutivos (em todos os sentidos) empreendimentos econômicos, como é o caso da construção de represas ou implementação de polos industriais sem que reações equivalentes da intelectualidade do movimento de "minha terra virou parque" sejam esboçadas.

Estratégia parecida é adotada em dois momentos por Dourojeanni e Jorge-Pádua:

\footnotetext{
${ }^{16}$ É farto o uso de operadores argumentativos entre os autores. Nas citações reproduzidas até aqui, temos: bem demonstrado; forte efeito; exemplo recente; impacto muito significativo; inúmeros trabalhos; casos mais desastrosos; visita recente; grande número; correlação altamente significativa; evidências claras; impacto bastante evidente; é patente o conflito; é bastante claro; gravemente impactada; sofreu graves problemas; em muitos casos; um dos melhores exemplos; pesquisas detalhadas; a maior parte; algo surpreendente; um grande número; atacou fortemente; muitas vezes; certas situações; séria deterioração; relevantes trabalhos; vários estudos; muitos casos; muitos estudos recentes; pesquisas sérias; são contundentes; hay miles de opiniones; más probable; absolutamente, não é verdade; problemas amplamente documentados.
} 
[...] é válida a pergunta: por que não invadem terras subutilizadas de fazendas, como até agora faz o MST? Sob o critério de serem donos de tudo, bem poderiam reclamar terras nas capitais dos estados, onde se supõe que eram seus territórios, digamos São Paulo ou Rio de Janeiro [...]. É difícil entender que se aceita a ideia de se manter e financiar museus, em geral para benefício da elite social da América Latina, enquanto se dá a entender que os parques não têm futuro porque "os pobres do meio rural necessitam dos seus recursos". Os museus têm guardas armados defendendo-os dia e noite contra incursões dos pobres urbanos... por que isto é tão impensável em um parque? (Ibid., p. 147 e 197).

Este tipo de proposição paralela tende a desviar a atenção do leitor. Sobre esta tática de desvio, comenta Schopenhauer (1997, p. 160): "se percebemos que vamos ser derrotados, recorremos a um desvio, isto é, começamos de repente a falar de algo diferente, como se fosse pertinente à questão e constituísse argumento contra o adversário". Nos dois casos, desloca-se o debate sobre conflitos entre interesses conservacionistas e de populações locais e sobre a necessidade de retirar "comunidades e pessoas" para a criação de UCs. Milano direciona sua atenção para a questão da "construção de represas" e "polos industriais". Porém, se "pessoas e comunidades de todas as origens e índoles são sistematicamente deslocadas de suas terras em razão de grandes e destrutivos empreendimentos econômicos", isso não significa que esta prática seja, em si, desejável, pois uma coisa não valida nem anula automaticamente a outra. Embora ambas tenham algo em comum (levam pessoas a se "deslocar de suas terras"), trata-se de casos distintos, pois a construção de represas e polos industriais segue lógica, possui objetivos e desempenha funções bem diferentes das motivações que levam à criação de UCs. Aliás, em termos de conservação, seguem até mesmo lógica contrária, pois muitas UCs são criadas justamente como medida mitigadora dos impactos causados por tais empreendimentos.

O mesmo ocorre no caso da associação entre museus e parques. O desvio aparece na pergunta "por que não invadem [...]?" e ao se queixarem de, por um lado, ser "difícil entender que se aceita a ideia [...]" e, por outro, "enquanto se dá a entender que [...]". Ao citar o exemplo dos museus, tenta-se associá-los aos parques visando legitimar ações nestes de "guardas armados" não para evitar "incursões dos pobres urbanos", mas, por inferência, para impedir incursões de pobres rurais. Ainda que haja proximidade entre ambos (afinal, existem para conservar algo, sejam artefatos materiais de uma cultura, sejam amostras representativas da biodiversidade), museus e parques, assim como represas e UCs, são coisas bem distintas (sem falar que "guardas armados" não protegem museus só "contra incursões dos pobres urbanos", como vimos há dois anos no assalto ao Museu do $\mathrm{MASP}^{17}$ ).

Outro ponto de discórdia refere-se à anterioridade, isto é, quem teria chegado primeiro ao território em disputa: populações tradicionais ou UCs? De fato, realçar uma ou outra possibilidade confere grande legitimidade à argumentação. Dourojeanni e Jorge-Pádua alegam:

[...] [especificamente] em relação aos problemas indígenas em UCs [...], muitas UCs, por exemplo, as estabelecidas na Amazônia, foram cuidadosamente escrutinadas para se detectar presença humana no momento de seu estabelecimento. Mesmo que seja possível que em alguns casos este exame prévio não tenha sido suficientemente estrito, na maioria dos casos há evidência de que não existiam populações na área $\mathrm{e}$ muito poucas nas proximidades (Ibid., p. 133).

Apesar de reconhecer que pode ter havido equívocos "em alguns casos", estes não seriam representativos face ao processo geral. O que importa é que, "na maioria dos casos [...], não existiam populações" quando da criação de UCs, as quais, aliás, "foram cuidadosamente escrutinadas". Mas o que quero marcar neste trecho é que ele traz uma manobra comum usada para frear o poder de denúncias de ações coercitivas ligadas à criação de UCs: quando se está sob forte ataque, uma saída pode ser devolver a acusação. Pelo que é dito, pode-se concluir que: se "há evidência de que não existiam populações na área", isto significa que elas teriam chegado depois de a área virar UC. Aqui, trata-se do estratagema dialético schopenhaueriano retorsio argumenti: "remeter de volta o argumento do inimigo". Ao invés de dirigir a resposta ao caráter arbitrário e coercitivo ligado

\footnotetext{
${ }^{17}$ O fato foi amplamente divulgado. Conforme O Globo (15/02/2008), sobre o roubo no MASP do "Lavrador de Café" (Portinari) e "Retrato de Suzane Bloch" (Picasso): "terceiro suspeito é de classe média e tinha programa de TV em Goiás, tinha um perfil diferente dos outros dois criminosos, filho de fazendeiro e de uma advogada que mora num bairro nobre de Brasília".
} 
à criação de UCs, imputa-se às populações tradicionais a responsabilidade delas terem sido as invasoras. Com isto, há nova inversão e o jogo muda de figura, com acusados passando a acusadores. Com isso, neutraliza-se, em parte, o argumento baseado no uso de violência ou nos efeitos sociais perversos de ações repressoras advindas da criação de UCs, pois, se elas já existiam antes da chegada de populações tradicionais, seriam estas que, por sua própria conta e risco, teriam se colocado na situação em que se encontravam.

Adotando tal artifício, Olmos et al. (2001, p. 293297), através de vários exemplos, fazem uma reconstrução histórica de lugares e datas por onde teriam passado grupos Guarani para comprovar que, no caso das UCs onde vivem hoje, estes teriam chegado após sua criação:

[...] uma das áreas recentemente ocupadas pelos Guarani foi o Parque Nacional de Superagui, no Paraná. Segundo o IBAMA, índios vindos do Rio Grande do Sul e Santa Catarina teriam sido transportados pela FUNAI para lá em 1992 (Gazeta do Paraná, 19/11/2000). O fato é que não havia nenhuma ocupação indígena da área quando da criação do parque, e aliás muito tempo antes disso.

Seguindo o contra-ataque, Olmos et al. (2001, p. 292) carregam sua munição com casos onde esta "invasão" teria ocorrido: "em 19 de agosto de 1999, 300 Pataxós invadiram a sede do Parque Nacional Monte Pascoal, expulsando os funcionários do IBAMA à força". Dourojeanni e Jorge-Pádua (2001, p. 134 e 147), por sua vez, adotam mesma tática:

[...] indígenas contatados há pouco tempo [...] motivados ou empurrados por pessoas externas, têm protagonizado, especialmente no Brasil, ações espetaculares de "reconquista" de seus territórios, ocupando violentamente algumas UCs [...]. Como explicado, indígenas não completamente assimilados pela sociedade moderna são empurrados sobre as UCs e, quanto menos assimilados estão, preferem entrar nas UCs de uso indireto, pois nelas não há populações. Indígenas, sempre assessorados por não indígenas, começaram a reclamar essencialmente as terras das UCs de uso indireto, entre elas o Monte Pascoal, o Araguaia (belicosamente invadidos), Ilha do Cardoso, Intervales e Turvo, entre outros.
Como declamam Gilberto Carvalho e Raul Pereira (1976) na epígrafe "quando a bala vem por cima, companheiro, se abaixemo; quando a bala vem por baixo, companheiro, nós pulemo; mas se a bala vier no meio, há! fazemo a bala voltar!". Agora quem age violentamente não são autoridades ligadas à preservação ambiental, mas indígenas que estariam "expulsando funcionários" e "invadindo" UCs "belicosamente". Ao que então surgem outra vez exemplos (Monte Pascoal, Araguaia, Intervales, Ilha do Cardoso e Turvo) como artifício para fortalecer o que é dito. $\mathrm{O}$ efeito principal será nova mudança no foco da discussão. Mas deve-se ficar atento, pois certamente nova investida virá em breve contra-atacando o argumento da inversão. No caso do exemplo acima, por exemplo, nada garante que novos laudos da FUNAI venham a ser produzidos atestando a anterioridade Guarani nos territórios em disputa.

\section{Sobre encruzilhadas argumentativas $e$ controvérsias irresolutas}

Ao se falar sobre populações tradicionais e biodiversidade, polaridades argumentativas surgem com força, evidenciando a elevada alteridade aí presente. Se, por vezes, o debate possui certa fluidez (GERHARDT, 2008), vimos que dele emergem pontos de vista bem demarcados, sendo que, para acentuar distinções, divergências assumem a forma concreta de controvérsias discursivas onde, conforme Deleuze (2006), a oposição é a representação máxima da diferença. Mobilizando a atenção de número expressivo de especialistas, estes, ao discutirem o tema de distintos modos e intensidades, precisam ao menos reconhecer a existência desta divisão. Podem não concordar com as teses de seus colegas, se recusar a tomar posição definida ou ainda não aceitar a validade da controvérsia, mas, ainda assim, não poderão evitá-la.

Como está em jogo a fabricação das discussões, cientistas buscam - a partir de debates circunstanciais compostos por pequenas traições e lealdades disciplinares - conquistar e defender territórios discursivos ou, ao contrário, retomá-los via contra-ataques argumentativos. Para tanto, lançam mão de certas táticas (citar casos, fatos e estimativas, arregimentar aliados, atacar referências inimigas, retorcer argumentos, deslocar questões, inverter e reinverter o ônus da culpa etc.). Assim, se os debatedores procuram fixar suas conclusões em "caixas-pretas" (LATOUR, 2000), isto é, certezas que servem de instrumentos (como pressupostos) 
usados na conquista de outros territórios, por outro lado, eles estão constantemente investindo contra as bases conceituais e a prioris que garantem segurança aos territórios inimigos.

Um viés problemático desta guerra por evidências é que ela pode levar a um debate retórico sem fim. Vimos não ser difícil trazer exemplos de populações tradicionais que teriam contribuído para reduzir a biodiversidade, mas, também, achar casos em que teriam ajudado a preservá-la (dentro ou fora de UCs) não seria trabalhoso. Como me disse Cristina Adams ao entrevistá-la, "se você está do lado das populações você descobre isso, se está do lado da natureza, enfim, descobre outros argumentos" (GERHARDT, 2008, p. 185). Ladeira (2004, p. 241) explicita tal aspecto ao comentar a relação entre povos indígenas e meio ambiente:

[...] duas concepções correntes sobre a relação dos índios com a natureza se contrapõem. Uma delas se funda na ideia inspiradora de harmonia entre índios e natureza e a outra de que práticas tradicionais de subsistência indígena são destrutivas e desequilibradoras. Essas concepções dificultam a compreensão sobre a relação das sociedades indígenas e seu ambiente e a busca de alternativas concretas de conservação.

Como o modo de lidar com a questão é proporcional à imaginação daquele que a discute, há forte tendência de, no futuro, este exaustivo debate se tornar, prescritiva e analiticamente, deveras improdutivo. Ao discutir a questão a partir da lógica do "ou isto ou aquilo", batalhas argumentativas ligadas à relação entre biodiversidade e populações tradicionais têm forte chance de seguir o mesmo rumo do "efeito SLOSS" descrito por Morsello (2001): serem relegadas a um "um interesse histórico"18. Afinal, se sempre teremos exemplos disponíveis para reforçar a tese de que populações tradicionais usam seus recursos de modo insustentável, igualmente não será difícil encontrar exemplos de grupos locais que manejam tais recursos de modo sustentável. Não há saída para tal dilema, pois, conforme Bourdieu (1998, p. 177), “existe um monte de 'fontes', reais ou presumidas, jogando lenha na fogueira das disputas eruditas". Aurélio Rios (2004, p. 83-84) percebeu bem este aspecto da discussão:
[...] em nada auxilia o debate e as formas possíveis de conciliação dos interesses da preservação ambiental e da manutenção de populações tradicionais nos seus territórios a indicação de exemplos extremos de degradação ambiental que possam ter sido causados por populações tradicionais às Unidades de Conservação [...] ou o descaso causado pelo abandono e má gestão de áreas protegidas [...]. Os casos ilustrativos de desmandos e má gestão dos recursos naturais pouco contribuem ao debate se deles se extrai, como regra ou princípio, a exclusão das populações tradicionais do manejo dos Parques e Reservas ou, ao contrário, a impossibilidade de qualquer intervenção da autoridade pública em caso de uso insustentável e sistemático de recursos naturais por parte de populações residentes nas áreas protegidas.

Em suma, controvérsias sobre bons ou maus selvagens ou sobre a propensão intrínseca ou natural de populações tradicionais para a conservação ou destruição da biodiversidade, além de levar a infindáveis contestações de parte a parte, parecem ser analiticamente estéreis. Constitui armadilha interpretativa arriscada imaginar que populações tradicionais possuiriam o dom ou da preservação ou da destruição ambiental inoculado em suas práticas sociais. Em termos analíticos, o mesmo ocorre ao pensar tais grupos sociais tanto como infratores como protetores, pessoas prontas para, na primeira oportunidade, exterminar ou, ao contrário, cuidar dos recursos de que dispõem. O mesmo ocorre quando se rotulam seus saberes e experiências acumuladas tanto como se fosse algo inferior, inculto, atrasado, ignorante, primitivo, como se representassem algo verdadeiro, puro, superior, harmônico. Por outro lado, se grupos sociais culturalmente diferenciados são ou não os mais indicados para cuidar da natureza, na maioria dos casos possuem menor poder de fazer valer seus pontos de vista. O que significa que, além do interesse geral (seja ele qual for), seria preciso considerar, como elemento central, as desigualdades sociais e especificidades circunstanciais envolvidas. A meu ver, partir desta premissa ética como sul a orientar nossas ações evitaria uma série de situações inoportunas e constrangedoras tanto em termos de justiça social como de conservação ambiental.

De fato, há quem não aceite tão facilmente as regras do jogo subjacentes à discussão. Na mesma linha de Rios

\footnotetext{
${ }^{18}$ O debate SLOSS, abreviatura de "single large or several small", durou anos sem que os cientistas envolvidos chegassem a uma solução ou consenso (a não ser, talvez, sobre a irrelevância de continuar a debatê-lo). Segundo Morselo (2001, p. 91), chegou-se à conclusão de que ausência de uma resolução para o debate "está na complexidade inerente ao processo de seleção de reservas. Não existem regras simples e aplicáveis que possam ser generalizadas para qualquer lugar e situação”.
} 
e Ladeira, Raul Valle (2004, p. 314), falando sobre "direitos dos índios e direitos da natureza" envolvendo grupos Guarani e UCs na Mata Atlântica, apresenta de forma clara a possibilidade de estar em curso uma batalha discursiva cujo final não terá vencedores:

[...] argumentos levantados por aqueles que se debruçam sobre o problema são fundamentados em preceitos morais, mesmo quando se propõem a analisá-lo de forma "técnica". As discussões sobre a anterioridade da presença humana em determinada região, ou a íntima relação entre biodiversidade e sociodiversidade, só fazem sentido se analisadas à luz da moral, se compreendidos os valores que estão sendo confrontados, pois suas conclusões - díspares em muitos casos - servirão para justificar determinada solução para o problema perante a sociedade em geral. Assim, quando vemos que informações sobre a presença histórica de determinado povo indígena na região "sob disputa" vêm sendo usadas por ambas as partes da contenda para construírem seus argumentos e para justificarem suas posições, logo percebemos que há um princípio ético. [...] as partes envolvidas nesse dilema brigam, cada qual, para implementar uma solução que privilegie aqueles valores por ela defendidos $[\ldots]$.

Por estarem alicerçadas em "preceitos morais", como lembra Valle, há grande chance de estarmos diante de uma controvérsia irresoluta, visto que entrar num debate marcado por visões muito distantes implica juízos de apreciação cujos fundamentos levam a trilhas distintas. Portanto, a meu ver, um primeiro passo a ser dado por aquele que adentra neste campo de disputas seria assumir o fato de que não se trata só de uma polêmica estritamente científica ou técnica. Como tentei mostrar em outro momento (GERHARDT, 2008), tais desencontros não se restringem às distintas influências teóricas, metodológicas e epistemológicas dos envolvidos (o que tende a levar a generalizações naturalizantes do tipo: cientistas sociais $\mathrm{X}$ cientistas naturais, antropólogos X biólogos, ecólogos X sociólogos etc.). Mais do que isso, divergências entre pesquisadores resultam de posições assumidas a partir de valores e orientações éticas em que suas trajetórias e redes de relações exercem papel decisivo (GERHARDT, 2008).

Obviamente, os confrontos implicam, sim, um emaranhado de macro e microcontrovérsias científicas (que ora se confundem, se mesclam, se distinguem, desaparecem ou emergem). Mas os debatedores, mais do que pretender observar, descrever, conhecer e compreender processos sociais e fenômenos naturais, agem politicamente, ou seja, se suas habilidades e competências acadêmicas possuem força e legitimidade, elas não se encontram soltas entre as esferas de poder mais amplas. Em suma, há diferentes intencionalidades em jogo, as quais estão constantemente sendo negociadas, adaptadas e, por que não, alteradas.

Isto significa que, no caso do debate sobre biodiversidade e populações tradicionais, estamos a todo instante diante do desafio de assumir posições (até porque pesquisar já subentende a necessidade de se fazer escolhas). Decidir enfrentá-lo é mais ou menos como chegar numa encruzilhada: se queremos dele participar, poderemos escolher um caminho, atalho ou mesmo ficar parados no meio da encruzilhada. Ao optar por adotar pressupostos, teses e argumentos já defendidos por outros colegas, poderemos descobrir paisagens que lhes passaram despercebidas; porém, também é possível terminarmos replicando e mimetizando comentários já gastos e antigos. Ao optar por seguir um atalho desconhecido (uma hipótese não testada, por exemplo), talvez cheguemos a novos insights criativos; mas há também o perigo de, no final, termos de recusar tal hipótese ou, se nela insistirmos, de a vermos ser visceralmente destruída por algum colega. Já se ficarmos parados no meio da encruzilhada (observando os que passam e refletindo sobre suas decisões), vejo duas possibilidades: uma é simplesmente ficar para trás e ser esquecido pelos demais (ou seja, nossos trabalhos não serão mais citados, não viraremos referência, nossas ideias não sendo nem reforçadas nem refutadas pelos colegas); a outra é que, passado algum tempo, os viajantes que haviam seguido em frente comecem a retornar, já que as trilhas escolhidas, tal como num labirinto, os fizeram andar em círculos. Em todo caso, teremos de escolher para onde vamos (ou não vamos).

Aqui vejo papel o fundamental a ser exercido por aqueles (pesquisadores ou não) que, no futuro próximo, se interessarão pela questão, pois estes tendem a não aceitar, tão fácil e tacitamente, as regras deste jogo político-interpretativo deveras corrosivo. Creio que deles saberemos então, quando recontarem e reinventarem a história que vivemos e fazemos hoje a partir das pegadas e rastros que deixamos, quantas voltas demos no labirinto controvertido do debate sobre populações tradicionais e biodiversidade. De qualquer modo, olhando para a quantidade de certezas que nossa própria ciência já produziu e, depois de algum tempo, ela própria negou tanto no caso de critérios adotados 
para delimitar áreas prioritárias à conservação como no que se refere à compreensão sobre os significados analíticos e usos políticos da categoria populações tradicionais, me parece que, para aqueles que se aventuram por estes temas,

\section{Referências}

ADAMS, C. Caiçaras na mata atlântica: pesquisa científica versus planejamento e gestão ambiental. São Paulo: Annablume-FAPESP, 2000

AMEND S. E.; AMEND, T. Espacio sin habitantes? Parques Nacionales de América del Sur. Caracas: IUCN-Gland/Nova Sociedad, 1992.

ARRUDA, R. Populações tradicionais e a proteção dos recursos naturais em unidades de conservação. In: DIEGUES, A. C. Etnoconservação: novos rumos para a proteção da natureza nos trópicos. São Paulo: Hucitec/Annablume, 2000.

AZEVEDO, J. R. A conservação da paisagem como alternativa à criação de áreas protegidas: um estudo de caso do vale do Rio Negro na região do Pantanal - MS. Dissertação (Mestrado em Ciências Ambientais) - PROCAM - USP. São Paulo: 2002.

BENSUSAN, N. Terras indígenas: as primeiras UCs. In: RICARDO, F. (Org.). Terras indigenas e unidades de conservação: o desafio das sobreposições. São Paulo: Instituto Socioambiental, 2004.

BOURDIEU, P. Meditações pascalianas. Oeiras: Celta Editora, 1998.

. Os usos sociais da ciência: por uma sociologia clínica do campo científico. São Paulo: Editora UNESP, 2004.

BRASIL. Sistema Nacional de Unidades de Conservação. Brasília: MMA, 2000.

CARVALHO, G.; PEREIRA, R. Leão do Caverá. In: VI Califórnia da Canção Nativa. Uruguaiana/RS. Disco (60 min.). Porto Alegre: 1976.

COLCHESTER, M. Resgatando a natureza: comunidades tradicionais e áreas protegidas. In: DIEGUES, A. C. Etnoconservação: novos rumos para a proteção da natureza nos trópicos. São Paulo: Annablume, 2000.

CUNHA, M. C. A convenção da diversidade biológica e suas repercussões no Brasil. Estudos Avançados, v. 13, n. 36, 1999.

DELEUZE, G. Diferença e repetição. Rio de Janeiro: Graal, 2006. adotar uma postura mais modesta seria não só prudente, mas menos arriscada em relação aos efeitos de suas explicações, conclusões e proposições.

DIEGUES, A. C. O mito da natureza intocada. São Paulo: HUCITEC, 1996.

. Etnoconservação da natureza: enfoques alternativos. In: DIEGUES, A. C. Etnoconservação: novos rumos para a proteção da natureza nos trópicos. São Paulo: Hucitec/Annablume, 2000.

; NOGARA, P. O nosso lugar virou parque. São Paulo: NUPAUB: USP, 1994.

DOUROJEANNI, M. Áreas protegidas de América Latina em los albores del siglo XXI. In: BENJAMIN, A. H. (Coord.) Direito Ambiental das Áreas Protegidas: o regime jurídico das unidades de conservação. Rio de Janeiro: Forense, 2001.

DOUROJEANNI, M.; JORGE-PÁDUA, M. T. Biodiversidade: a hora decisiva. Curitiba: Editora UFPR, 2001.

DUCROT, O. Princípios de semântica linguística. São Paulo: Cultrix, 1976

FERNANDEZ, F. O poema imperfeito: crônicas de biologia, conservação da natureza e seus heróis. Curitiba: Editora UFPR, 2004.

FOUCAULT, M. Microfisica do poder. Rio de Janeiro: Graal, 1979.

. Discorso e verità nella Grecia Antica. Edizione italiana a cura di Adelina Galeotti. Roma: Donzelli Editore, 1997.

GALETTI, M.; OLMOS, F.; BERNARDO, C. A conservação e o futuro da Jureia: isolamento ecológico e impacto humano. In: RICARDO, F. (Org.) Terras indigenas e unidades de conservação: o desafio das sobreposições. São Paulo: Instituto Socioambiental, 2004.

GERHARDT, C. A invisibilização do outro nos discursos científicos sobre áreas naturais protegidas In: CONGRESSO BRASILEIRO DE SOCIOLOGIA, 13. UFPE, Recife (PE), 2007.

.Pesquisadores, populações locais e áreas protegidas: entre a instabilidade dos "lados" e a multiplicidade estrutural das "posições". Tese (Doutorado em Ciências Sociais) - Universidade Federal Rural do Rio de Janeiro. Rio de Janeiro: CPDA-UFRJ, 2008. 
GUHA, R. O biólogo autoritário e a arrogância do anti-humanismo In: DIEGUES, A. C. Etnoconservação: novos rumos para a proteção da natureza nos trópicos. São Paulo: Hucitec/Annablume, 2000.

KOCH, I. G. V. A inter-ação pela linguagem. São Paulo: Contexto, 2004.

LADEIRA, M. I. Terras indígenas e unidades de conservação na mata atlântica: áreas protegidas? In: RICARDO, F. (Org.). Terras indígenas e unidades de conservação: o desafio das sobreposições. São Paulo: Instituto Socioambiental, 2004.

LATOUR, B. Jamais fomos modernos. São Paulo: Editora 34, 1994.

Ciência em ação: como seguir cientistas e engenheiros sociedade afora. São Paulo: Editora UNESP, 2000.

Ecologia política sem natureza. In: Ver. Proj. Histórica, São Paulo, n. 23, 2001.

. A esperança de Pandora: ensaios sobre a realidade dos estudos científicos. Bauru, SP: EDUSC, 2001.

MILANO, M. Unidades de Conservação: técnica, lei e ética para a conservação da biodiversidade. In: BENJAMIN, A. H. (Coord.). Direito Ambiental das Áreas Protegidas: o regime jurídico das unidades de conservação. Rio de Janeiro: Forense, 2001.

Por que existem as unidades de conservação? In: MILANO, M. (Org.). Unidades de conservação: atualidades e tendências. Curitiba: Fundação O Boticário de Proteção à Natureza, 2002.

MORSELLO, C. Áreas protegidas públicas e privadas. São Paulo: Annablume, 2001.

OLMOS, F.; ALBUQUERQUE, J.; GALETTI, M.; MILANO, M.; CÂMARA, I.; COIMBRA-FILHO, A.; PACHECO, J.; BAUER, C.; PENA, C. FREITAS, T.; PIZO, M.; ALEIXO, A. Correção política e biodiversidade: a crescente ameaça das "populações tradicionais" à Mata Atlântica. In: ALBUQUERQUE, J. L. (Org.). Ornitologia e conservação: das ciências às estratégias. Tubarão: Editora Unisul, 2001.

RIOS, A. V. Populações tradicionais em áreas protegidas. In: RICARDO, F. Terras indigenas e unidades de conservação da natureza: o desafio das sobreposições. São Paulo: Instituto Socioambiental, 2004.

SANTILLI, J. Socioambientalismo e novos direitos. São Paulo/ Peirópolis: Instituto Socioambiental, 2005.

SARKAR, S. Restaurando o mundo selvagem. In: DIEGUES, A. C. Etnoconservação: novos rumos para a proteção da natureza nos trópicos. São Paulo: Hucitec/Annablume, 2000.

SCHOPENHAUER, A. Como vencer um debate sem precisar ter razão: em 38 estratagemas (dialética erística). Rio de Janeiro: Topbooks, 1997.

VALLE, R. S. T. Direitos dos índios ou direitos da natureza: um debate acerca de direitos humanos. In: RICARDO, F. (Org.) Terras indigenas e unidades de conservação: o desafio das sobreposições. São Paulo: Instituto Socioambiental, 2004.

Recebido em dezembro de 2009.

Aceito em setembro de 2010.

Publicado em dezembro de 2010 